Kayış, Y. (2021). Ragıp Kemal Cantürk'ün gezi yazılarında Bursa. Uludağ Üniversitesi Fen-Edebiyat Fakültesi Sosyal Bilimler Dergisi, 22(41), 1371-1419.

DOI: $10.21550 /$ sosbilder.881764

Araştırma Makalesi / Research Article

\title{
RAGIP KEMAL CANTÜRK'ÜN GEZİ YAZILARINDA BURSA
}

Yasin KAYIŞ*

Gönderim Tarihi / Sending Date: 16 Şubat / February 2021

Kabul Tarihi / Acceptance Date: 17 Nisan / April 2021

\section{ÖZET}

Ragıp Kemal Cantürk 1930'ların ilk yarısında Anadolu ve Trakya'yı dolaşarak gezi yazıları kaleme almış bir muhabirdir. Gezilerini Milliyet, Akşam ve Vakit (Kurun) gazeteleri adına yapmış, özellikle Marmara Denizi çevresindeki kentleri daha sık ziyaret etmiştir. Cantürk'ün sıkça ŭgradı̆̆ yerlerden biri de Bursa vilâyetidir. Söz konusu gezilerinde Cantürk vilâyet merkezinin yanı sıra Mudanya, Gemlik, Inegöl, Orhaneli, Karacabey, Mustafakemalpaşa ve Orhangazi kazalarını da ziyaret etmiş̧tir. Ancak bu çalışma muhabirin sadece vilâyet merkezine dair gezi yazılarına odaklanmiştır. Cantürk, Bursa vilâyet merkezine dair yazllarında kentin belediye, eğitim, ulaşım gibi kamu hizmetlerini değerlendirmiş, ekonomik etkinliklerine dair bilgiler vermiştir. Bursa'nın tarım ürünlerinin bolluğunu, kalitesini ve ucuzluğunu sürekli vurgulayan Cantürk, ayrıca turizm, merinos koyun yetiştiriciliği, ipekli dokuma gibi farklı sektörlere dair de detaylı bilgiler paylaşmışıtır.

Anahtar Kelimeler: gezi yazısl, Bursa, turizm, Uludağ, basın

\section{Bursa in The Travel Articles of Ragıp Kemal Cantürk}

\section{ABSTRACT}

Ragip Kemal Cantürk is a reporter who traveled Anatolia and Thrace in the first half of the 1930s and wrote travel articles. He traveled on behalf of Milliyet, Akşam, and Vakit (Kurun) newspapers and visited the cities around the Marmara Sea more frequently. The districts of Mudanya, Gemlik, Inegöl, Orhaneli, Karacabey, Mustafakemalpaşa, and Orhangazi as well as one of the places Cantürk visited frequently is Bursa province. During his trips, Cantürk visited the provincial center. However, this study focused only on the reporter's travel articles about the provincial

Dr., Tarih Öğretmeni, İzmir Cumhuriyet Eğitim Müzesi, İzmir / TÜRKIYYE, ykayis@hotmail.com

Uludağ Üniversitesi Fen-Edebiyat Fakültesi Sosyal Bilimler Dergisi Uludağ University Faculty of Arts and Sciences Journal of Social Sciences

Cilt: 22 Sayı: 41 / Volume: 22 Issue: 41 
center. In his articles on Bursa province center, Cantürk evaluated public services such as the city's municipality, education, and transportation, and provided information on its economic activities. Cantürk, who constantly emphasized the abundance, quality, and cheapness of Bursa's agricultural products, also shared detailed information on different sectors such as tourism, merino sheep breeding, and silk weaving.

Key words: travel articles, Bursa, tourism, Uludağ, press

\section{Giriş}

Ragıp Kemal Cantürk, 1931 yılında kurmay albay ${ }^{1}$ rütbesiyle ordudan emekli olmadan önce gazetelerde gezi yazıları kaleme almaya başlamış, emekli olduktan sonra da bu faaliyetini sürdürmüş bir muhabirdir. 1930-36 y1llarında Milliyet, Akşam ve Vakit (Kurun) gazetelerinde çalışmıştır. Yıllarca Anadolu ve Trakya'yı dolaşarak mektup hâlinde gönderdiği yazılar bu gazetelerin sütunlarında yayınlanmış, muhabir daha sonraki yıllarda "Akıl Hocası" adıyla pratik bilgiler içeren bir yayın hazırlamaya başlamıştır.

1876 yılında Erzurum'da doğan Cantürk, Ahmet Vefik Bey’in oğludur $^{2}$. 1897'de girdiği Topçu Harp Okulundan 1900 yılında üsteğmen rütbesiyle mezun olmuş; Balkan Savaşı (1912-13), I. Dünya Savaşı (1914-1918) ve İstiklâl Savaşı'na (1919-1922) katılmıştır. 1916’da Muharebe Gümüş Liyakat Madalyası ile ödüllendirilmiştir. Son olarak 8.

1 Cantürk’ün Kara Kuvvetleri Komutanllğı Emeklilik Şubesi Arşivindeki şahsi dosyasına dayanılarak hazırlanan yayında "kurmay" olduğuna dair bir bilgi yer almamıştır (Genelkurmay Başkanlığı, 2010: 237-238). Ancak Cantürk 1938'de Kadıköy'de kaleme aldığı Akıl Hocası adlı eserinin önsözünü "Erkânıharbiye miralayı mütekaidi” olarak imzalamıştır (1938: 11). Aynı eserin ikinci fasikülünde ise bu kez “emekli kurmay albay" unvanını kullanmıştır (1939: [87]).

2 Cantürk Bafra'ya dair bir gezi yazısında, babasının bir zamanlar Bafra'da kaymakamlık görevinde bulunduğunu bu yüzden de kendisinin Bafra'nın yabancısı olmadığını belirtmiştir (Bafra sıtmadan bunalmış vaziyettedir, 1932). 
Ordu bünyesinde, 4. Kolordu Şube Müdürlüğü görevindeyken emekli olmuştur (Genelkurmay Başkanlığ1, 2010: 237-238).

Emekli olduktan sonra gezip yazmaya odaklanan muhabir kimi zaman üç-dört aylık süreyi evinden uzaklarda geçirmiştir. 1936'ya kadar süren bu gezilerinde Karadeniz kıylarını, Batı Anadolu'yu, Antalya ve Çukurova'yı, bir seferinde de Güneydoğu Anadolu'nun bir kısmını gezip görmüş, izlenimlerini okuyucularına anlatmıştır. Ancak gerek gezi güzergâhları üzerinde olması gerekse de ulaşım kolaylığı nedeniyle Marmara Denizi çevresindeki vilâyetler Ragıp Kemal Bey'in başlıca uğrak noktaları olmuştur. İzlenimlerini anlattığı yazılarını "R.K." rumuzuyla, "R. Kemal" kisaltmasiyla veya "Ragip Kemal" adıyla imzalayan muhabir, 1935 yılında "Cantürk" soyadını almış ve imzasında soyadını da kullanmaya başlamıştır.

Cantürk gezip gördüğü yerlerde adeta bir müfettiş titizliğiyle gözlemler yapmıştır. Yalnızca şehir merkezlerini ve resmi kurumları görmekle yetinmemiş, ayrıca nahiyeleri ve köyleri de ziyaret etmiştir. Kimi zaman valilerle, belediye başkanlarılyla ve bürokratlarla temasta bulunmuş kimi zaman da çarş1-pazar, kahvehane sohbetleriyle halkın arasına karışmış, onların dertlerine tercüman olarak devletle halk arasında bir köprü vazifesi görmeye çalışmıştır. Onun gezi yazılarında henüz yeni doğmuş bir devletin kuruluş sancılarını, başarılarınıbaşarısızlıklarını, eksiklerini ve yapabildiklerini görmek mümkündür. Öte yandan muhabirin tam da Dünya Ekonomik Krizi'nin etkilerinin yoğun olarak hissedildiği bir zaman diliminde kaleme aldığı mektuplar krizin fiyatlar, üretim ilişkileri ve halk üzerindeki etkilerini değerlendirmek açısından önemli ipuçları vermektedir.

Ragıp Kemal Cantürk'ün sıkça ziyaret ettiği vilâyetlerden biri de Bursa'dır. Gezi yazıları incelendiğinde muhabirin 1931-1934 yıllarında altı kez Bursa'yı ziyaret ettiği anlaşılmaktadır. Cantürk bu ziyaretlerinde Bursa şehrinin yanı sıra Mudanya, Gemlik, Orhaneli, Orhangazi, 
Karacabey ve Mustafakemalpaşa kazalarını da gezip görmüş, birçok gezi yazısı kaleme almıştır. Bunlardan Bursa vilâyet merkezini konu alan on sekizi bu çalışmanın konusunu oluşturmaktadır.

\section{Ragıp Kemal Bey'in Kaleminden Bursa'nın Genel Tanıtımı}

1930'lu yılların ilk yarısında Bursa vilâyeti, merkez kazası ile beraber on kazadan oluşuyordu (Sedad, 1934: 1). 1927 nüfus sayımına göre vilâyetin toplam nüfusu 401.595, merkez kazasının nüfusu ise 127.251'di. Merkez kazasına bağlı Kestel ve Soğukpınar adıyla iki nahiye, 167 tane de köy mevcuttu (T.C. Devlet Y1llı̆̆ 1 , 1930: 302-303). 1934 yılında Bursa merkez kazasının nüfusu 135.783 'e, vilâyetin toplam nüfusu ise 415.519'a yükselmişti (Sedad, 1934: 29). Yüzölçümü bakımından Türkiye'nin \% 1,5'luk alanını kapsayan Bursa vilâyetinde kilometrekareye otuz kişi düşüyordu. Vilâyet bu nüfus yoğunluğuyla ülke çapında önemli bir yere sahipti (R.K., Bursa, bir fabrikalar şehri halini ald1, 1931).

Ragıp Kemal Bey'e göre Bursa sadece Türkiye'de değil dünyada müstesna bir konuma sahipti. Hem doğal güzellikleriyle hem de ekonomik zenginlikleriyle göz dolduruyordu. Mektuplarından birinde kenti okuyucusuna şu sözlerle tanıtmıştır:

"Bursa şehri kürei arz üzerinde emsaline tesadüf edilmiyen feyyaz ve cenneti âsa bir yerdir! Fitrat burada bütün cömertliğini göstermiştir: Lâtif bir hava, her tarafta şarıl şarıl akan temiz ve şeker gibi sular, zümrüt gibi yeşil hareli ovalar, sıcak ve şifalı çelik ve kükürtlü kaplıcalar, ipek kumaşlar, tüylü havlular, güzel kokulu iri ve sulu şeftaliler ve her ç̧eşit meyvalar nefis karpuzlar, mebzul sebzeler hep bu mübarek vilâyete mahsustur.” (Ragıp Kemal, Bursada yapılan yeni binalar, 1931)

Farklı mevsimlerde kenti ziyaret eden muhabir kış aylarındaki bir ziyaretinde Bursa'yı yaza oranla daha sönük ve soğuk bulacağını tahmin ederek gelmişti. Gerçekten de yaza göre bir durgunluk vardı. Ama vardığ 1 sırada kent adeta bahar havası yaşıyordu. İki gün sonra hava birdenbire bozup kar yağsa da bir gün sonra yeniden yaz manzarasını

Uludağ Üniversitesi Fen-Edebiyat Fakültesi Sosyal Bilimler Dergisi Uludağ University Faculty of Arts and Sciences Journal of Social Sciences Cilt: 22 Sayı: 41/Volume: 22 Issue: 41 
almıştı. Ragıp Kemal Bey bu havalar karşısında “Zaten Bursa'nın kışı çok nazlıdır derler! Öyle birden bire bastırmaz, herkese mahrukat tedariki imkânını verdikten sonra nisana doğru esip savurmağa başlar" diyerek Bursa'nın havası hakkındaki genel kanaati aktarmıştır (Ragıp Kemal, Bursadaki merinoslar nasıl 1slah ediliyor?, 1932).

Ziyaretleri sırasında Bursa'nın kent dişından pek çok konuk ağırladığını aktaran ve turizm potansiyelini bizzat gözlemleme imkânı bulan Ragıp Kemal Bey kendi sorduğu "Niçin herkes Bursaya koşuyor?" sorusunun yanıtını yine kendisi şöyle veriyordu:

"Tabiat ve hilkat Bursaya büyük hazineler bahşetmiştir. Havasının ve suyunun güzelliği, her türlü hastalıklara şifa olan kaplıcaları, sıcak ve yakıcı havalarda Uludağın karlı tepeleri, meyva ve sebzesinin bolluğu, hiç bir yerde emsali bulunmıyan şeftalisile kestanesi, armudu, ayvası, kaymağı, tereyağı, sütü, peyniri, kaşarı, ipek işleri, havlusu, tütünü, bıçağı, kebabı, köftesi velhasıl Nilüfer vadisinin gönül açıcı manzarası ve saymakla tükenmiyen bin bir nimetleri hep bu tarihî şehre nasip olan tabiî servet ve saadetlerdir.

Cenabı hakkın öbür dünyada insanlara vadeylemiş olduğu saadet ve nimetlerin hepsi burada mevcut olduğundan dünyada iken bir kerecik olsun cennet hayatı yaşamak istiyenlerin behemehal buraya gelmelerini tavsiye eylerim. Çünkü: Hayattan zevk almak, vücudun zayiatını tamamlamak burada mümkün olur.

Bursanın tabiî güzelliklerinden başka ecdadın, vücuda getirmiş olduğu öyle muazzam abideler, öyle sanatkârane yapılmış eserler vardır ki bunların bir mislini daha yapmağa ve başka memleketlerde bunların bir örneğini görmeğe imkân yoktur!” (Ragıp Kemal, Bursa bir sene içinde çok değişti, 1933)

\section{Belediye Hizmetleri ve Kent Dokusu}

Ragıp Kemal Bey'in başka pek çok kentte olduğu gibi Bursa'da da en çok üzerinde durduğu konulardan biri belediye hizmetleri olmuştur. Muhabirin, 1931 yılındaki ilk ziyareti sırasında Belediye Başkanı olarak Nazifi Şerif Bey görev yapıyordu. Muhabir, başkanı makamında ziyaret 
etmiş ve Bursa Belediyesi'nin ehil ellerde olduğu izlenimini edinmiştir. Nazifi Şerif Bey çok değerli ve Bursalılar tarafından çok sevilen bir kişiydi. Karşısındakine güven veren bir tavrı vardı. Bursalılar bu başkandan kentin bayındırlığı ve refahı konusunda çok şey ümit ediyordu (R.K., Bursa, bir fabrikalar şehri halini aldı, 1931).

Bursa Belediyesi'nin 1931 y1l itibariyle geliri 400.000 lirayd1. Belediye Başkanı Nazifi Şerif Bey, o zamana kadar toz ve çamurdan geçilmeyen Kaplıcalar Caddesi'ni Uludağ'dan kestirdiği taşlarla döşetmek için çalışmalara başlamıştı. 300.000 taş, yol üzerine nakledilmişti. Bir ay sonra bu taşların döşenmesine başlanacak ve ilk etapta Gazi'nin köşküne kadar olan bölüm tamamlanacaktı. Tüm yolun tamamlanması için ise 1.000.000 kesme "paket taşı" gerekliydi. İki yılda ve iki etap hâlinde tüm işin bitirilmesi planlanmıştı (R.K., Bursa, bir fabrikalar şehri halini aldı, 1931).

İtfaiyenin arozözü ve iki motorbüsü vardı. İtfaiye için bir garaj inşa edilmiş, ancak uzman heyetin hatasından dolayı yapımının tamamlanmasından hemen sonra büyük bir gürültüyle yıkılmıştı. Sorumlu mühendis hemen azledilmiş ve mahkemeye sevk edilmişti. Uygun bir yere garaj ve tatbikat alanı içeren modern bir bina yapılması için de çalışmalara başlanmıştı (R.K., Bursa, bir fabrikalar şehri halini ald1, 1931).

Ragıp Kemal Bey, 1931 baharındaki ziyareti sırasında özellikle belediye binasından çok etkilenmiş, bina hakkında detaylı bilgiler paylaşmıştır. Muamelât Müdürü Ali Rıza Bey'in konukseverliği ve ikramları ile bu salonda yarım saat kadar bulunan muhabirin verdiği bilgilere göre binanın girişi ve dört merdiveni çok hoştu. Üst katta büyük ve muhteşem bir salon vardı ki muhabirin tahminine göre böyle bir salon başka hiçbir belediye binasında yoktu. Salonun tavanı ve duvarları rengârenk ampullerle döşeliydi ve salon doğaya uygun bir şekilde süslenmişti. Ampuller aynı anda yakıldığında insan kendini adeta bir 
cennet köşkünde hissediyordu. Salonun bir cephesinde bulunan Gazi'nin büyük portresi 1şıklı bir çerçeve içine alınmıştı ki Ragıp Kemal Bey, Gazi'nin büyüklük ve gücüyle uyumlu bu kadar muhteşem ve canlı bir tabloyu o zamana kadar görmediğini belirtmiştir (R.K., Bursa, bir fabrikalar şehri halini aldı, 1931).

Muhabir aynı yılın sonbaharında yeniden Bursa'yı ziyaret ettiğinde Belediye Başkanı değişmişti. 1931'in Nisan ayında Dr. Nazifi Şerif (Nabel) Bey'in yerine Muhittin (Dinçsoy) Bey göreve başlamıştı (Bilgi, 2006: 40). Muhabir bu ziyareti sırasında Bursa halkıyla yaptığ1 temaslar sonucunda, halkın şikâyetlerini sekiz başlıkta özetlemiş ve Bursa'nın yeni Belediye Başkanı Muhittin Bey’in dikkatini çekmişti. Bu sorunlar şöyleydi:

1- Bursa'da tavuklara yem yerine böcek verilmekte olduğu için hem yumurtalar hem de tavuklar adeta leş gibi kokuyordu. Bu durum yumurta ve tavukların Bursa dışına satışına olumsuz etki yapıyordu.

2- Bahçelerin lâğım sularıyla sulandığına dair söylentiler vardı. Doğruluğu hâlinde bu durumun engellenmesi gerekiyordu.

3- Pınarbaşı suyu en kirli işlerde kullanılıp pislendikten sonra Hisar, Yahudilik, Muradiye halkı tarafından içme suyu olarak kullanılıyordu. Bu söylenti de doğru ise Bursa halkı tehlikede demekti.

4- Mahalle arasındaki fabrikaların gürültüsü halkın huzur ve rahatını kaçırıyordu. Herkes bundan rahatsızdı ve bir çözüm istiyordu.

5- Devrengeç suyu yalnız Setbaşı'na akıtılıyordu. Bu suyun, Ulu Cami çınarları yanında çeşmeler yapılarak oraya kadar uzatılması çok yerinde bir hizmet olacaktı.

6- Kentteki su sıkıntısına bir çözüm bulmak gerekiyordu. Bunun için Kavak suyunun Gökdere suyuna eklenmesi lâzımdı. Yollarda köylüler bir bardak su için gönekleri kırmakta olduğundan suyun kaynağından demir borularla Gökdere’ye bağlanması gerekliydi. 
7- Halkın evlerdeki suları israf etmesi ve bunun da kentte susuzluğa sebep olması nedeniyle evlere su saati takılmasının uygun olacağı görüşü hâkimdi.

8- Kahvelerde kullanılan sazdan yapılmış sandalyeler mikrop bulaştırmaya çok müsaitti. Bunların engellenerek yerlerine tahtadan yapılan sandalyelerin kullanılması doğru olacaktı (R.K., Bursalıların dertleri, 1931).

Muhabir 1932 kışındaki ziyareti sırasında, eskiden kaplıcalara gidip gelenlerin toz-toprak içerisinde kaldığ 1 Çekirge yolunun kısmen kaldırım taşıyla kısmen de şose olarak düzgün bir hâle getirildiğini görmüş ve bunu önemli bir gelişim olarak kaydetmiştir. Böylece gelecek yaz, yolun bazen sulanmasıyla halkın temiz bir şekilde kaplıcalara gidip gelmesi mümkün olacaktı. Belediye Başkanı Muhiddin Bey'in bu çalışmayla takdir toplayacağına şüphe yoktu (Ragıp Kemal, Bursadaki merinoslar nasıl 1slah ediliyor?, 1932).

Ragip Kemal Bey, 1932 y1lındaki ikinci gezisinde kentte yeni yapılan bazı binaların eleştiri konusu olduğunu aktarmış ve eleştirileri destekler tarzda yorumlar yapmıştır. Söz konusu binalardan biri Tayyare Cemiyeti tarafından büyük zorluklarla inşa edilmiş olan sinema binasıydı ve binanın mimarisi beğenilmiyordu. Projesi uluslararası bir yarışma ile belirlenen ve 1200 kişi kapasiteli büyük bir salona sahip bu bina geniş bir iç hacme sahip olmasına rağmen gerçekten de dışarıdan basık görünüyordu (Aladağ, 2004: 81). Bir yıl önceki yazısında bu binayı bir "anıt"a ve "kanatlarını açan bir kartal"a benzeterek öven, "muazzam" olarak nitelendiren (Ragıp Kemal, Bursada yapılan yeni binalar, 1931) muhabir belli ki bir yıl sonra eleştirilerin etkisi altında kalmış veya gördüğü manzara karşısında fikir değiştirmiştir. Çünkü bu kez aynı bina için asıl cephesinin adeta kaplumbağa baş1 gibi küçücük göründüğünü, muazzam gövdesi çukurda ve gözlerden uzak kaldığ 1 için de halk üzerinde olumlu bir izlenim bırakamadığını yazmıştır. Aktardığına göre 
eleştiri konusu diğer bina ise yeni yapılan kaplıcaydı. Servinaz ve Hüsnü Güzel kaplıcalarının olduğu yerde inşa edilmemiş olması ve bu kaplıcanın suyunun hâlâ temin edilememiş olması rahatsızlık doğurmuştu. Milyonlar harcanarak yapılan ve Bursa için birer iftihar abidesi olması gereken bu iki binanın yerlerinin iyi seçilememiş olması ve birinin önceden suyu getirilmeden temelinin atılmış olması, şehrin dokusuna güzellik getirmeyen bir planla yapılması halk tarafından eleştiriliyordu (Ragıp Kemal, Kaplıca şehrinde göze çarpan şeyler, 1932).

Yaklaşı bir yıl aradan sonra Bursa'yı yeniden ziyaret eden Ragıp Kemal Bey, bu süre içerisinde Bursa'da pek çok değişikliğin olduğunu görmüştür. Muhiddin Bey'in Belediye Başkanı olmasından sonra Bursa'nın görünümünde çok olumlu değişimler meydana geldiğini belirten muhabir bunları ayrı ayrı yazmanın uzun süreceğini, Bursa'nın eski ve yeni hâlini bilenlerin farkı bir bakışta görebileceğini söylemiştir (Ragıp Kemal, Bursa bu sene çok kalabalık ve eğlenceli, 1933). Bir yıl içerisinde Tayyare binası tamamlanmış, cadde üzerinde çıkıntı oluşturan hamam yıkılarak yerine iki güzel apartmanın inşasına başlanmıştı. Gazi heykelinin önünden Setbaşı'na kestirme olarak yeni bir cadde daha açılmış, Dörtyol'dan tren hattına giden şose çok güzel şekilde tamir edilmiş, Çatalfırın'dan stadyuma kadar olan şosenin üzeri kaldırımla döşenmişti (Ragıp Kemal, Bursa bir sene içinde çok değişti, 1933).

Ragıp Kemal Bey'e göre Bursa'nın en zor ve en karmaşık hizmetleri belediyenin omuzlarındaydı. Ancak Belediye Başkanı Muhiddin Bey'in gece-gündüz çalışması sonucunda Bursa halkı ile Bursa'ya gelen ziyaretçiler rahat ediyordu. Ne var ki Bursa'da iyi ekmek bulmak mümkün değildi. Muhabire göre firıncılar ya kasten kötü ekmek yapıyorlar ya da ekmek yapmayı bilmiyorlardı. Buna bağlı olarak belediyede her gün ekmekle ilgili gürültü kopuyordu. Her gün birkaç firının ekmeklerine el konulduğu ve çeşitli cezalar verildiği hâlde 
firıncılar yine de bunlardan ders çıkarmıyordu (Ragıp Kemal, Bursa ve Mudanyada yılan avcıları, 1933).

1934 yılında kenti belediyecilik açısından değerlendiren muhabir son üç yıl içerisinde Bursa Belediyesi'nin çok iş gördüğünü özellikle de son iki yılda kentin tanınamayacak kadar değiştiğini söylemiştir. Sağlık işlerine gösterilen dikkat ve özen sayesinde yiyecek ve içecek maddeleri sıkı bir kontrol altına alınmış, eski oteller çağdaş bir hâle getirilmişti. Toplu taşıma seferleri düzene sokulmuş, mevcut hatlardan başka Muradiye taraflarına da otobüs seferleri başlatılmıştı. Bundan dolayı halk Belediye'ye müteşekkirdi. Belediye ayrıca şehrin su ve elektrik işlerini de yoluna koymuştu. Ancak yapılan tesisat yeterli değildi. Bunu geliştirmek için de çareler düşünülmüş ve su gücüyle ucuz elektrik üretimine karar verilmişti (Ragıp Kemal, Bursada hararetli bir belediye faaliyeti var, 1934).

Muhabirin 1934 yılındaki ziyareti sirasında Belediye yeni projeleri hayata geçirmeye devam ediyordu. Belediye Başkanı Muhiddin Bey Belediye bahçesinde kışlık bir gazino yaptırmaya başlamıştı. Böylece kentin önemli bir sosyal ihtiyacı karşılanacak, gazino bünyesindeki geniş salonlar davetlilere, ziyafetlere, düğün ve eğlenceler ile her türlü toplantıya açık bulundurulacaktı (Ragıp Kemal, Bursada hararetli bir belediye faaliyeti var, 1934). Ama muhabire göre Belediye'nin memnuniyet uyandıracak en önemli hizmeti, şehrin girişindeki Altıparmak adasını kaldırmaya girişmiş olmasıydı. Bunun için birçok bina yıktırılmıştı. Başka harap binaların da yıkılması gündemdeydi (Ragıp Kemal, Bursada hararetli bir belediye faaliyeti var, 1934). Altıparmak Caddesi, Gazi Bulvarı gibi genişletilecekti. Böylece Yeşil Bursa kenti Mudanya tarafından girişindeki herkesçe bilinen çirkin görünümden kurtulacak ve şerefine yakışır bir hâl alacaktı (Ragıp Kemal, Bursa ovasındaki sulama ve kurutma ameliyat1, 1934). 


\section{Vilâyet Yönetimi}

Ragıp Kemal Bey Bursa vilâyetinin yönetimi hakkında en detaylı bilgileri 1933 yılındaki gezisi esnasında vermiştir. Muhabirin bu ziyareti sırasında Bursa'nın valisi yeni değişmiş daha önce Antalya'da vali olarak görev yapan Abidin Bey Bursa'ya atanmıştı. Abidin Bey önceden Bursa'da polis müdürü, Mudanya'da da kaymakam olarak bulunmuş, Mudanya'daki görevi sırasında Yunanlılar tarafından tutuklanmış ve idama mahkûm edilerek Yunanistan'a götürülmüsstü. Abidin Bey'in diğer esirlerle birlikte anavatana dönüşü, Gazi Mustafa Kemal Paşa'nın başarıları ve müdahalesi sonucunda gerçekleşebilmişti. Muhabire göre yeni Vali Bursa'daki görevine yeni başladığı için kendisinden bir şey beklemek yanlış olurdu. Abidin Bey henüz kazaları ziyaret ve teftiş ediyor, odasının kapısını sonuna kadar açarak halkın sorunlarını dinliyordu. Herkes Bursa'nın daha fazla gelişmesi için yeni Vali'den ümitliydi. Onun zekâsı, çalışkanlığı, tecrübesi, namus ve iffeti de bu ümitleri destekliyordu (Ragıp Kemal, Bursa bir sene içinde çok değişti, 1933).

Muhabirin bu gezisi sırasında Bursa'da hâlâ derli toplu bir hükümet konağ1 yoktu. Valilik makamı geçici olarak, özel idarenin yaptırmış olduğu bir otelde bulunuyordu. Hükümet dairelerinin bir kısmı başka yerlerdeydi. Yeni Vali Abidin Bey Ziraat, Baytar ve Başmühendislik dairelerini Tayyare Sineması binasına naklettirmiş, uzak yerlerde bulunan Emniyet Müdürlüğü ile Jandarma Kumandanlığını Valilik makamının olduğu binaya aldırmıştı (Ragıp Kemal, Yol parasını yol inşaatına hasretmek lâzım, 1933). Vilâyet yönetim kadrolarında önemli değişiklikler de yapılmış Emniyet Müdürü, Jandarma Kumandanı, Baytar Müdürü, Nafia Başmühendisi, Halk Fırkası İdare Reisi ve Maarif Müdürü değişmişti (Ragıp Kemal, Bursa vilâyetinde hayvan hastalıklarile mücadele, 1933). 
Önceki Maarif Müdürü Bursa'da güzel izler bırakarak Edirne'ye gitmiş, yerine tecrübeli bir eğitimci olan Şakir Bey atanmıştı. Eğitim için yeni adımlar atılmaya başlanmıştı. Okulu olmayan köy çocuklarının eğitimi için okul binası uygun olan köylerde öğrenci pansiyonları açılacaktı. Vali Abidin Bey pansiyon yerleri ile binalarını bizzat denetliyordu. Bu pansiyonlarda kalacak çocuklar sekiz aylık iaşelerini getirecekti. Öte yandan Maarif Cemiyeti'nin yönetimindeki öğrenci yurdu dağılmış ve borçlarını kapatmak için yurdun eşyalarını Maarif Vekâleti satın almıştı. Bundan başka, üst üste iki-üç yıl olumsuz rapor alan öğretmenler tasfiye edilecek, yerlerine meslekten yetişmiş olan öğretmenler getirilecek ve "muallim muavini" istihdamına gerek kalmayacaktı (Ragıp Kemal, Bursa vilâyetinde hayvan hastalıklarile mücadele, 1933).

Bursa'nın büyük bir şehir olmasına ve polis sayısının da az olmasına rağmen her tarafta huzur ve asayiş yerindeydi. Bunun da en önemli sebebi yeni Emniyet Müdürü Faik Bey'in gücüydü (Ragıp Kemal, Bursa ve Mudanyada yılan avcılar1, 1933).

Ezan meselesinin ${ }^{3}$ ardından işten el çektirilen müddeiumuminin yerine henüz kimse atanmadığından, onun yerine Müddeiumumi Fahri Bey tarafından vekâlet ediliyordu. O sıralarda Fahri Bey'in en önemli meşguliyeti Bursa soyguncularının ${ }^{4}$ tahkikatıydı ve soygunculardan üçü henüz yakalanamamıştı. Vilâyet çapındaki asayiş vakalarının çoğunluğu

31 Şubat 1933'te Bursa'da ezanın Türkçe okunmasına karşı çıkan olaylar kastedilmektedir.

${ }^{4} 2$ Haziran 1933'te Bursa-Orhaneli yolunda bir yol kesme, soygun ve cinayet hadisesi yaşanmıştı. Basında "Bursa Soygunu” olarak adlandırılan olay sırasında soygun çetesi kırk kadar kişiyi soymuş, bir jandarma ile bir sivili öldürmüş, bir jandarmayı da yaralayarak kayıplara karışmıştı. Olay sonrasında yapılan takibat sonucunda çete üyeleri Samsun, Rize, İstanbul gibi farklı kentlerde yakalanarak yargılanmak üzere Bursa'ya gönderilmişti (Bursa Yolunda Bir Şekâvet, 1933; Musa, 1933; Samsunda tutulan Bursa soyguncuları dün sabah İstanbula getirildiler, 1933). 
hırsızlıktı. Muhabirin verdiği bilgiye göre bu işleri yapanlar ve mahkemeleri en çok uğraştıranlar "kıpti tayfası"ydı. Hapishanedeki tutuklu ve hükümlü sayısı ise 800 kişiydi (Ragıp Kemal, Yol parasını yol inşaatına hasretmek lâzım, 1933).

Vilâyet Baytar Müdürü Şefik Bey’in Karacabey Harası Müdürlüğüne atanmasından sonra onun yerine gelen Baytar Tahsin Nahit Bey, Şefik Bey’in eksikliğini hissettirmiyordu. Yeni Baytar Müdürü, özellikle merinos koyunlarının çoğaltılması ve korunması için tedbirler almıştı. Vilâyet çapında özellikle şarbon ve keçi uyuzu önem arz ediyordu. Orhaneli kazası hariç vilâyetin tamamında şarbon mikrobu görülüyordu. Bulaştığı yerlerde uzun süre yaşayan bu mikroplar yalnız hayvanların değil insanların da ölümüne neden olabildiği için şarbon konusunda gerekli hassasiyet gösteriliyordu. Buna rağmen cehalet sebebiyle gerekli mercilere müracaat etmeyip "karaçiban" vb. şekilde adlandırılan şarbondan ölenlerin sayısı az değildi. 1933 yılı itibariyle mücadeleye başlanmış ve yüz bini aşkın hayvan aşılanmıştı ${ }^{5}$ (Ragıp Kemal, Bursa vilâyetinde hayvan hastalıklarile mücadele, 1933).

Bursa'nın malî durumu iyiydi. Vergi tahsilâtı miktarı geçen yıllara göre artmıştı. Emeklilerin aylıkları düzenli hâle getirilmiş, görevi kötüye kullandıkları tespit edilen memurların görevine son verilmişti. Beş tahsildardan üçü hapis cezası almış ikisi de firar etmişti. Dokuz yıllık tecrübeye sahip olan Defterdar Rüştü Bey ise çalışkan ve maliye işlerine

5 Uygulanan aşıları Ankara'daki Baytarî Merkez Laboratuvarı Şefi ve Baytar Kaymakamı olan Süreyya Tahsin Bey geliştirmişti. Daha önce Pastör Enstitüsü tarafından üretilen şarbon aşısının formülünü bulan bu genç baytar, aşıyı üretmeyi başarmış ve bu aşıya "Süreyya Tahsin Şarbon Vaksini" adı verilmişti. Bu genç bilim insanı bir yıl önce de binlerce hayvanın ölümüne sebep olan sığır vebasına karşı aşı geliştirmişti. Bu icadıyla domuz vebasına karşı Macar bilim insanlarına ilham veren Süreyya Tahsin Bey Askeri Baytar Mektebi mezunuydu. Ayrıca Almanya'da da eğitim almıştı ve Ziraat Vekâleti bünyesinde çalışıyordu (Ragıp Kemal, Bursa vilâyetinde hayvan hastalıklarile mücadele, 1933). 
hâkim biriydi (Ragıp Kemal, Yol parasını yol inşaatına hasretmek lâzım, 1933).

\section{Bayındırlık Hizmetleri}

\subsection{Ulaşım}

Bursa'nın ulaşımında kilit öneme sahip Mudanya ve Yalova yolları Cumhuriyet' in ilk yıllarında da önemini koruyordu. Bu iki kaza özellikle Bursa-İstanbul arasındaki ulaşım için son derece önemliydi. Her iki iskele ile Bursa arasında, vapurların ulaşımına göre hareket eden otobüsler, kaptıkaçtılar, otobüsler işliyordu. Mudanya güzergâhında karayolunun yanı sıra demiryolundan da yararlanmak mümkündü (Bilgi, 2006: 79, 82).

Ragıp Kemal Bey'in verdiği bilgilere göre 1931 yılı itibariyle Bursa vilâyeti şose yollar açısından iyi hâldeydi. Bu açıdan Bursa tıpkı Balıkesir ve Kars gibi övgüyü hak ediyordu. Ancak bu yorumu yapan muhabir detaylara girdikçe çelişkiye düşmüştür. Zira her kazadan vilâyet merkezine "mükemmel şoseler" olduğunu söylemiş olmasına rağmen aynı cümlenin devamında ise "bazıları bozulmuş olduğundan ihale suretile ve tamiratı mütemadiye usulile 1slahına ihtimam olunmaktadır" demiştir (R.K., Bursa, maarifi çok mütekâsif bir şehirdir, 1931).

Verdiği bilgilere göre yine aynı yıl Gemlik-Kumla ve KumlaYalova arasında 38 kilometrelik bir yolun inşası kararlaştırılmış ve keşfi yapılmıştı. Bu yolun keşif bedeli 900.000 lira olduğu için ödeneği Nafia Vekâleti tarafindan verilecekti. Yol yapımı için Nafia garajında 10 silindir ve 2 konkasör mevcuttu. Bursa'dan Apolyond (Ulubat) gölünün güneyini izleyerek Mustafakemalpaşa'ya da kestirme bir yol yapılacak ve $88 \mathrm{~km}$ uzunluğunda olan eski şose $24 \mathrm{~km}$ kısalacaktı. Bu yolun iki başından inşaat başlamış ve orta kısımdaki 21 kilometrelik bölümün tamamlanmasına az kalmıştı (R.K., Bursa, maarifi çok mütekâsif bir şehirdir, 1931). 
1931 sonbaharında "delik deşik" hâldeki Mudanya-Bursa yolunu kullanmış olan Ragıp Kemal Bey dört ay sonra aynı yolun mükemmel bir şekilde tamir edilmiş olduğunu görmüş, bindiği otomobil şosenin üzerinde adeta "yağ gibi kayarak" kısa sürede onu Bursa'ya getirmişti. Durumdan memnun olan muhabir, "Gönül ister ki bu şosa bütün sene böylece kalsın ve mütemadiyen tamire mazhar olsun! Zira Bursa'nın en işlek yolu burasıdır ve halk bu yolun güzelliği veya çirkinliğile Bursa hakkındaki hükmünü vermektedir" demiştir (Ragıp Kemal, Bursadaki merinoslar nasıl sslah ediliyor?, 1932).

Muhabirin 1933 yılında bildirdiğine göre Valiliğin, Başmühendis ve ekibinin kıymetli çalışmalarına rağmen Bursa'nın yolları hâlâ bozuktu. Bunun da başlıca sebebi yol için toplanan paraların başka yerlere sarf edilmesiydi. Örneğin 103.000 liraya ihale olunan Gemlik ve Karacabey yollarının bir buçuk yılda tamamlanması ve paralarının da üç yılda ödenmesi gerektiği hâlde 1932 ve 1933 yıllarında sadece 50.000 lira tahsisat verilebilmişti. Mudanya yolunun bazı kısımları bozuk olmakla birlikte bazı kısımları çok güzeldi. Bu yol üzerinde iki silindir tamirat için çalışıyordu. Karacabey yolundaki tamirata da önem verilmiş, bu yol üzerinde de üç silindir görevlendirilmişti (Ragıp Kemal, Yol parasını yol inşaatına hasretmek lâzım, 1933).

1933 y1lı itibariyle Bursa vilâyetindeki şoselerin uzunluğu 700 $\mathrm{km}$ idi. Vilâyetin yol tahsisatı ise 47.000 lirayd1. Bunun da 12.000-17.400 lirası sürekli tamirat için ayrılmıştı. Ancak köprülerin hepsinin ahşap olduğu ve sadece bunların tamiri için bile her y1l 8.000 lira harcandığ 1 göz önünde bulundurulunca ayrılan tahsisatın ne kadar yetersiz olduğu ortaya çıkıyordu.

Ragıp Kemal Bey'e göre yol yapım, bakım ve onarım çalışmalarındaki aksaklığın temel nedeni merkezi yönetimden 
kaynaklanıyordu. Bir önceki Nafia Vekili Recep (Peker) Bey'in ${ }^{6}$ döneminde (1927-1933) yol parasının yollara tahsis edildiğini hatırlatan muhabir, Recep Bey'den sonra bu usulün terkedildiğini, paranın \% 15'ini Nafia Vekâletinin aldığını geri kalanın da vilâyetteki (Maarif, Ziraat, Baytar vb.) müdüriyetler arasında paylaştırıldığını, bunun da yol yapım ve onarımını aksattığını belirtmiştir. Ragıp Kemal Bey'e göre yol meselesinin kolayca halledilebilmesi için Nafia Vekâletinin yol siyasetini gözden geçirmesi ve Recep (Peker) Bey zamanındaki kanunun tekrar yürürlüğe konulması gerekiyordu (Ragıp Kemal, Yol parasını yol inşaatına hasretmek lâzım, 1933).

\subsection{Bursa Ovasinın Islahı}

Bursa'nın önemli sorunlarından biri ovayı baştanbaşa kateden Nilüfer Çayı ile Deliçay, Kaplıkaya, Hanife ve Kirmastı derelerinin mecralarının dolmuş olması ve bu akarsuların hemen her yıl taşarak ovayı sular altında bırakmasıydı. Baskınlar sebebiyle ürünler su altında kalyyor, vilâyet ve ülke ekonomisi büyük zarar görüyordu (Sedad, 1934: 77). Bursa'da geniş yer kaplayan bataklıkların kurutulması işi II. Meşrutiyet Dönemi'nde vilâyet yönetimi ile nezaretlerin gündeminde gelmiş ancak ekonomik koşullar nedeniyle çözüm sağlanamamıştı (Öztürk, 2014: 219). Ragıp Kemal Bey 1934 y1lındaki gezisinde Bursa'ya gidip gelenlerin pek de dikkatini çekmeyen ama Bursa için çok önemli bulduğu bu konudaki çalışmalar hakkında müjdeli haberler vermiştir. Çünkü hükümet bu sorunun önüne geçmek için büyük bir fedakârlık yapmış ve üç milyon lira gibi önemli bir bütçe ayırmıştı.

$\mathrm{Bu}$ iş, önceki Nafia vekillerinden merhum Süleyman Sırrı Bey zamanında gündeme gelmiş, sonradan bu göreve gelen Recep (Peker) Bey'in vekâleti zamanında da "büyük su siyaseti"ne başlanmıştı. Recep

\footnotetext{
${ }^{6}$ Recep Peker 1928-1930 yıllarında Nafia Vekili (Bayındırlık Bakanı) olarak görev yapmıştır (Bayrak, 1992: 42, 144).

Uludağ Üniversitesi Fen-Edebiyat Fakültesi Sosyal Bilimler Dergisi Uludağ University Faculty of Arts and Sciences Journal of Social Sciences Cilt: 22 Sayı: 41/Volume: 22 Issue: 41
} 
Bey, bu ova hakkında yapılan inceleme ve değerlendirmeleri dikkate alarak 1929 yılında kesin kararını vermişti. Aynı yılın Şubat ayında, kanalların açılması için yapılan ihale Bakkalbaşızade Nuri Bey’e kalmış ve sözleşmesi yapılmıştı.

O güne kadar açllan kanalların uzunluğu 70 km'yi bulmuştu. Bu iş için beş ekskavatör ${ }^{7}$ ile birçok silindir ve konkasör ${ }^{8}$ çalışıyordu. $\mathrm{Bu}$ kanalların açılması için üç sebep vardı. Bunlardan ilki sel ve su baskınlarının verdiği zararların önüne geçmek, ikincisi bataklıkları kurutmak ve üçüncüsü de kurutulacak bataklıkların ve civar arazinin sulanmasıydı. Haşerelerin önüne geçmek için Deliçay ve kolları sslah edilerek taşmalarına son verilmişti. 1934 yılı itibariyle de Nilüfer Çayı'nın zararlarının engellenmesine çalışlıyordu. 20-30 bin dönüm büyüklüğündeki Serme bataklığı ile etrafındaki bataklıklar da kurutulmuştu. Yenişehir yolundaki Aksu'nun sularıyla oluşan gölün önüne büyük bir toprak bendi yapılmıştı. Orada toplanan $15.000 .000 \mathrm{~m}^{2}$ su, arazinin sulanması için kullanılacaktı (Ragıp Kemal, Bursa ovasındaki sulama ve kurutma ameliyatı, 1934).

\section{5. Ĕgitim}

Ziyaret ettiği kentlerde özellikle okulları ziyaret eden ve eğitim konularına özel bir önem veren Ragıp Kemal Bey, Bursa'da da aynı duyarlılığ göstermiş̧tir. Bursa'ya yaptığı seyahatleri sırasında Necati Bey Kız Enstitüsünü, Himaye-i Etfal şubesinin kreşlerini, Bursa Askeri Lisesini ve İstiklal Mektebini gezmiş, eğitimcilerle görüşmüş ve Bursa'daki eğitimin genel görünümünü mercek altına almıştır.

Muhabirin verdiği bilgiye göre Cumhuriyet Devri'nin nimetleriyle birlikte Bursa miskinlikten sıyrılmış ve bir gelişme döneminde girmişti. Bir zamanlar eğitimlerini medrese ve taş

\footnotetext{
${ }^{7}$ Orijinal metinde "isklavatör" yazılmıştır.

${ }^{8}$ Orijinal metinde "fonkasör" yazılmıştır.
} 
mekteplerde yapmaya mecbur tutulan Türk çocukları artık her türlü özenle eğitimlerine devam ediyordu (R.K., Bursa, maarifi çok mütekâsif bir şehirdir, 1931).

1931 y1lı itibariyle Bursa tıpkı Balıkesir, Erzurum, Kars ve Trabzon gibi eğitim işlerinin yoğun olduğu yerlerden biriydi. Vilâyet çapında 305 okul ve 573 öğretmen eğitimin hizmetindeydi. Vilâyet merkezinde bir erkek lisesi, bir karma ortaokul, bir kız öğretmen okulu, bir erkek san'atlar mektebi, bir askeri lise, bir (Necati Bey) kız san'at enstitüsü, 24 ilkokul ve 3 anaokulu vardı (R.K., Bursa, maarifi çok mütekâsif bir şehirdir, 1931).

1931 ilkbaharındaki ziyareti sırasında tavsiye üzerine Necati Bey Kız Enstitüsünü ziyaret eden Ragıp Kemal Bey, Okul Müdiresi Melek Hanım tarafından sıcak şekilde ağırlanmış ve onun eşliğinde tüm okulu baştanbaşa gezmiştir. Ayrılırken de bir akşam sonra sahnelenecek olan müsamereye Müdire Hanım tarafından davet edilmiştir.

Okulun Müdiresi Melek Hanım on dört yıl önce İstanbul K1z Sanayi Mektebinden mezun olmuş, birçok kurs görmüş ve ustalar yanında çalışarak mesleğinde ilerlemişti. Uzmanlık alanı biçki ve dikişti. Çalışmayı tercih etmiş ve eğitimciliğe olan tutkusu sebebiyle de o güne kadar evlenmemiş, aile kurmamıştı. Okulun bir bölümünde oturuyordu.

Fransızlardan satın alınmış olan bu okul, 1929 yılında merhum (Milli Eğitim Bakanı) Necati Bey’in adıyla sanat enstitüsü hâline getirilmiş ve kızların eğitimine tahsis edilmişti. Okulda 14 öğretmen, bir muhasip görev yapıyor, $87 \mathrm{k} 1 \mathrm{z}$ eğitim görüyordu. İlkokul mezunlarının kabul edildiği bu okul orta dereceliydi. Henüz üç sınıfı vardı. Ancak zamanla beş sınıflı olacaktı. Bu okulda eğitim görenlerin atölyelerde çalışması, sınavla okullarda el işi öğretmenliği yapabilmesi mümkün olduğu gibi mükemmel bir ev kadını olarak yetişmeleri de söz konusuydu. 
Ragip Kemal Bey o güne kadar hiçbir okulda görmediği, tek kişilik masa ve sandalyeleri bu Enstitünün dershanelerinde görmüş ve şaşırmıştır. Her tarafta gördüğü temizlik ve düzeni okulun yetkin ellerde olduğunun göstergesi olarak değerlendirmiştir. Öğrencilerin el işleri ile dikişleri en titiz kişileri bile memnun edecek güzellikteydi. Özellikle şapkacılık takdire şayan şekilde bir ilerleme göstermişti. Şehit Kaymakam Şevki Bey'in kızı Öğretmen Aliye Hanım'ın yaptığı veya yaptırdığ 1 şapkalar Türk kadınlarını Avrupa ürünlerinden uzak tutacak kadar mükemmeldi. Okulun her tarafında Şehit Kubilay'ın resimleri asılmış ve hatırası yaşatılmaya çalışılmıştı (R.K., Bursa, maarifi çok mütekâsif bir şehirdir, 1931).

Bursa'da yıllık 10.400 lira geliri olan ve dokuz şubesi ile hizmet veren Himaye-i Etfal Cemiyeti de örnek gösterilebilecek bir faaliyet yürütüyordu. Cemiyetin idaresinde, biri Namazgâh'ta diğeri de Muradiye'de olmak üzere iki önemli kreş vardı. Ragıp Kemal Bey 1931'de bu kreşlerin ikisini de ziyaret etmiş ve gördüklerinden gurur duymuştur.

Fabrikalarda çalışan kadın ve erkek işçilerin çocukları akşama kadar bu kreşlerde bakılıyordu. Sabahleyin çocukların elbiseleri çıkarılarak torbalara konuyor ve kendilerine kreşin temiz elbiseleri giydiriliyordu. Çocuklar önce çaylarını içiyor, bir süre eğitim aldıktan sonra öğle yemeği yiyor ve kendilerine özel salıncaklarda 1-2 saat uyuyordu. İkindi çayını da içtikten sonra fabrikadan dönen annebabalarıyla birlikte eve dönüyordu. Her iki kreşte 100 çocuk bulunuyor; besin, giyim ve eğitim hizmeti alıyordu. Daha önce komşulara bırakılan çocuklar artık her çocuğa kısmet olmayan bir saygınlık ve refah ile büyütülüyordu. Bursa Himaye-i Etfal Cemiyeti Başkanı ve kreşlerin kurucusu Dr. Rıza Tahir Bey sürekli bir özenle bu kreşleri takip ediyordu. Kreşlerin müdürlüğünü ise Zehra ve Hikmet adlarında iki hanım yapıyordu (R.K., Bursanın gece hayatı da pek caziptir, 1931). 
Ragip Kemal Bey 1933 'teki gezisi sirasinda bir kez daha Himayei Etfal Cemiyeti hakkındaki olumlu görüşlerini okuyucularıyla paylaşmıştır. Verdiği bilgiye göre Bursa halkının en çok yararını gördüğü kurumlardan biri Himaye-i Etfal Cemiyeti idi. Cemiyetin başkanı Dr. Rıza Tahir Bey ile arkadaşlarının Bursa'ya verdikleri hizmet çok büyüktü. Cemiyetin doğuşunda Bursa halkının şefkat duyguları en önemli etken olmuş, Rıza Tahir Bey'in becerikli yönetimi de bu hayırlı işin devam etmesini sağlamıştı.

Rıza Tahir Bey'in kurmayı başardığ iki kreş fabrikalarda çalışan kadınların çocuklarına özenle bakmaya devam ediyordu. Bu kuruluşlar iftiharla görülmeğe lâyık birer çocuk yuvasıydı. Muhabire göre fabrikaları olan her şehirde bu gibi kreşler açılmalı ve böylece fakir ailelerin yükleri hafifletilmeliydi (Ragıp Kemal, Bursa ve Mudanyada yılan avcıları, 1933).

Muhabir 1933 yılındaki Bursa ziyareti sırasında, pek çok komutanı yetiştirmiş olan Bursa Askeri Lisesi'ne de konuk olmuştur (Ragıp Kemal, Bursanın kıymetli bir irfan müessesesi, 1933). Kendisi de asker kökenli olan muhabir okula sınıf arkadaşı Almanca Öğretmeni Fon Halil Bey ile birlikte gitmiş ve "Dâhiliye Müdürü" Kaymakam (Yarbay) Nami Bey'in eşliğinde bütün okulu baştan sona dolaşmıştır. Ragıp Kemal Bey'in verdiği bilgiye göre Nami Bey, yoğun çalışmalarıyla okulun gelişimine çok katkıda bulunmuş kıymetli bir askerdi.

Kuruluşu 1845 yılına kadar uzanan, mevcut binalarından ilki ise 1894 y1lında hizmete giren (Aladağ, 2004: 33) bu okul Uludağ'ın yamaçlarındaki doruklardan biri üzerinde yer alıyordu. Yerinin Müşir Fondergolç Paşa ${ }^{9}$ tarafından tavsiye edildiği söyleniyordu. İlk bina biraz

\footnotetext{
${ }^{9}$ Alman mareşali ve Osmanlı müşiri Wilhelm Leopold Colmar Freiherr von der Goltz, yarbaylığından itibaren Osmanlı ordusunun çeşitli kademelerinde görev yapmış ve Sultan II. Abdülhamit döneminde bir süre ordunun eğitim reformunu yönetmiştir. $\mathrm{Bu}$ bağlamda 1883-1895 yılları arasında Askeri Okullar Müfettişliği yapmıştır.
} 
küçük olduğu için sonradan birçok eklentiler yapılmış, okul önemli bir kurum hâline getirilmişti (Ragıp Kemal, Bursanın kıymetli bir irfan müessesesi, 1933).

Binanın genel görünümü ve bahçesi uzaktan bakınca adeta zarif bir tablo gibiydi. Okulun sarı rengi değiştirilerek koyu kurşunî bir renge boyanmış ve aralara da beyaz şeritler çe-kilmişti. Muhabire göre bu hâliyle binanın gösteriş ve büyüklüğü zarafetle birleşmiş ve seyrine doyulmaz bir hâl almıştı.

Güzel ve şirin şekilde düzenlenmiş olan havuzlu bir bahçenin içinden geçip beyaz merdivenlerden çıkılarak binanın nizamiye kapısına ulaşılıyordu. Binanın girişi askerliğin yüceliğini betimleyen levha ve resimlerle süslenmişti. Karşı cephede iki direk arasında Atatürk'ün savaş alanında topçu rasat dürbünü yanındaki kayalıkların arasında oturmuş hâlini gösteren bir tablo ile Atatürk'ün Gençliğe Hitabesi vardı. Söz konusu iki direk arasındaki sütunun üzerinde bu okuldan yetişmiş olan büyük kumandanların isimleri ve resimleri bulunuyordu. Bunlar arasında Müşir Redif Paşa ile Gazi Ahmet Muhtar, Müşir Esat, Müşir Ömer Rüştü Paşalar, Ferik Abdülkerim, Ferik Asım, Birinci Ferik Ali Sait, Ferik Ali Hikmet, Mirliva Sedat ve Ferik Nazmi Paşalar ile daha birçok miralay ve livaların isimleri yazılmıştı. Muhabire göre bu usul hem geçmiş nesilleri yâd etmek hem de gelecek nesilleri teşvik etmek için faydalıydı.

Muhabir okulun yemekhaneleri ile yatakhanelerini, kimya ve hikmet laboratuvarlarını, zengin kütüphanesini çok beğenmiş ve gördüğg̈ düzenden övgüyle söz etmiştir.

Okulun Müdürü, Erkânı Harbiye Miralayı (Kurmay Albay) Rasim Bey, yönetimdeki gücü ve eşine az rastlanır becerileriyle yalnız okul kadrosunun değil Bursa halkının da hayranlığını kazanmıştı. Öğrencilerin eğitim ve öğretimleri konusunda gösterilen özen sonuçlarını vermiş ve "genç aslan yavruları" büyük bir disiplinle yetiştirilmişti. 30 Ağustos Zafer Bayramı'ndaki törende bu okulun öğrencilerinin yanaşık 
düzende yaptığı geçit töreni halkın göğsünü kabartmış ve çok alkış almıştı.

Ragıp Kemal Bey’e göre 1934 yılında da Bursa'daki eğitim faaliyetleri övgüye değer durumdayd. Hem merkezde hem de kazalarda birçok yeni okul yapılmış, tamir gerektirenler de gözden kaçırılmamıştı (Ragip Kemal, Bursada hararetli bir belediye faaliyeti var, 1934).

Bursa'nın kamu yöneticileri açısından şanslı olduğunu belirten muhabire göre vilâyete atanan gerek valiler gerekse de diğer bürokratlar hep değerli ve iş bilir kişilerden oluşuyordu. Maarif müdürleri içerisinde çok değerli olan Celâl Mahir Bey'den sonra onunla aynı beceri ve değerde bir başka müdür atanmıştı. Özel İdarenin mali gücü el verdiğince eğitime önem verilmiş ve okul çağındaki çocukların okulsuz kalmamaları için çalışılmıştı.

Bursa'nın 875 köyünden 255 tanesinde okul vard1. 1934 yılı içerisinde 50 köyde okul yapılmış 29 okulun da inşasına başlanmıştı. Ayrıca 16 okul da tamir edilmişti. Vilâyet çapındaki 40.000 çocuktan 30.000'i okula alınmış ancak 10.000 çocuğa çare bulunamamıştı. Halkın yardımıyla yapılmış olan 288 okulda 567 öğretmen görev yapıyordu. Öğretmen başına 42 öğrenci düşüyordu ki bu da Maarif Kanunu'na uygundu $^{10}$. Bu okullardan başka ayrıca on üç pansiyon açılmıştı. Bunların sayısının yıl içerisinde elliye çıkarılmasına çalışılıyordu.

Millet mekteplerinde 5.114 kişi okutulmuş, köy bütçeleriyle 59 okuma odası yapılmıştı. Köy öğretmenleri ve müfettişlere bir yı1 içerisinde 529 konferans verdirilmiş ve bu konferanslar köylülerin anlayacakları şekilde sunulmuştu. Bir yıl önce Ziraat Mektebinde açılmış

\footnotetext{
${ }^{10}$ Ragıp Kemal Bey ya kendisine verilen sayıları kontrol etmemiş ya hesap hatası yapmış ya da iyimser bir tablo çizmek için çelişkiye düşmüş görünmektedir. Çünkü 567 öğretmenin 30.000 öğrenciye eğitim-öğretim verdiği göz önünde bulundurulduğunda öğretmen başına 42 değil 52,9 öğrenci düşmektedir.
} 
olan kurslara katılan öğretmenler ile köy öğretmenleri edindikleri bilgileri köylülere ve halka anlatmışlardı (Ragıp Kemal, Bursa ovasındaki sulama ve kurutma ameliyat1, 1934).

Muhabir, 29 Eylül 1934 tarihli Akşam gazetesinde yayımlanan mektubunda 29 yıllık bir emeğin sonucunda nihayet inşa edilen İstiklâl Mektebi hakkında detaylı bilgiler vermiştir. Şehrin kuzeyindeki Ahmet Paşayi Fenari mahallesinde betonarme olarak yapılan bu okul orta ve fakir ailelerin oturduğu 23 mahallenin merkezindeydi. Ragıp Kemal Bey'in verdiği bilgiye göre okulun inşa edilmesinin arkasındaki isim Vilâyet Encümeni Kâtibi Hasan Feyzi Bey'di. Hasan Feyzi Bey şehrin kenar mahallelerinde sefil hâlde dolaşan çocuklara bir okul yaptırmak için 29 yıl boyunca uğraşmış, 42 tutanak ve dilekçe sunmuş, bu süre içerisinde Bursa'da 23 vali ile 11 Maarif müdürü değişmişti. Hasan Feyzi Bey nihayet Vali Fatin Bey zamanında amacına ulaşmıştı. Bu mektebin inşa edilmesinde Erzurum'a tayin edilmiş olan önceki Maarif Müdürü Celâl Mahir Bey ile onun yerine gelen Maarif Müdürü Fakir Bey'in de emeği vardı.

İstiklâl Mektebinin iç ve dış görünüm açısından Bursa'da bir eşi daha yoktu. Okulda başöğretmen ve öğretmenler için iki oda, 11 dershane, üst katta biri oldukça büyük biri de küçük iki taraça, bodrum katında kız ve erkek tuvaletleri, kışlık teneffüs yerleri, yemekhane salonları, su ve elektrik tesisatı bulunuyordu. Bunlar gayet güzel inşa edilmişti.

$\mathrm{Bu}$ okul inşa edilirken etrafındaki dokuz ev satın alınarak bahçeye katılmıştı. Okulun kapladığı alan dört dönüm ise de bu yeterli görünmüyordu. İhtiyaca cevap verebilmesi ve tüm heybetiyle çevreden görülebilmesi için yakınından geçen İstiklâl Caddesi'ne kadar önü açılmalıydı. Bursa'nın yeni valisi Fazli Bey okulun son eksiklerini de tamamlamak için kolları sıvamış, bahçenin etrafina çevre duvarları yaptırmış, üzerine de demir parmaklıklar yapılması için girişımde 
bulunmuştu. Vali Bey ayrıca okulun etrafındaki köhne evlerin de yıkılması, okul bahçesinin hem İstiklâl Caddesi'ne hem de diğer taraftan açılacak yeni caddeye kadar genişletilmesi için çalışıyordu (Ragıp Kemal, Bursada hararetli bir belediye faaliyeti var, 1934).

\section{Ekonomi}

1927 y1lı itibariyle Türkiye'nin nüfus bakımından beşinci büyük kenti olan Bursa'nın ekonomisi sanayiye dayalıydı. Yağ, sabun ve şarap imalathaneleriyle ipekçilik kentteki sanayinin belkemiğini oluşturuyordu (Kaprol, 2002: 173). Aynı yıl Bursa merkez kazasında ekilen arazi 275.000 dönümdü. 65.550 dönümde bağcılık yapılıyor, 87.500 dönümde sebze ve meyve yetiştiriliyordu (Kaya, 1999: 231). Ayrıca merinos yünü üretimi diğer vilâyetlere göre daha gelişmişti. Tütün, zeytin, av derileri, meyan kökü gibi ürünleri yurt dışına ihraç ediliyordu. Sebze, meyve, hububat üretimi açısından verimli olan Bursa'da yıllık 1.000.000 kilodan fazla da pirinç üretiliyordu. I. Dünya Savaşı öncesinde başlanan gülyağı üretimi olumlu sonuçlar vermiş ancak savaş sebebiyle sona ermişti. Çekirge ile Bademli mıntıkasındaki kaplıcalar ise antik dönemden beri ünlüydü ve Cumhuriyet Dönemi'nde modernize edilmesine çalış1lıyordu (Sedad, 1934: 10, 78, 1).

Gezilerini 1929 Dünya Ekonomik Krizi’nin tüm dünyada olduğu gibi Türkiye'de de etkisini sürdürdüğü yıllarda yapan Ragıp Kemal Bey mektuplarında çok sık olmasa da krizin etkilerinden söz etmiştir. Ancak Bursa'ya dair yazılarına böyle bir etki yansımamıştır. Aksine muhabir kentteki tarımsal zenginlik ile üretim faaliyetlerinden övgüyle söz etmiş, piyasadaki ucuzluğu detaylı şekilde okuyucularıyla paylaşmıştır. Ne var $\mathrm{ki}$ bu ucuzluğun üretici üzerindeki etkisi üzerinde durmamıştır. Cantürk'ün mektuplarına yansıyan Bursa ekonomisi tarım ve hayvancılığa dayalı olmakla birlikte gerek ürün çeşitliliği gerekse de alternatif üretim imkânları sebebiyle oldukça canlıdır. Bununla birlikte 
muhabir, üreticilerin küresel krizden bağımsız bazı sıkıntılarını dile getirmiş ve yetkililerin dikkatini çekmeye çalışmıştır.

Bursa vilâyetindeki Yenişehir, Karacabey ve Mustafakemalpaşa ovalarının ziraat açısından dünya çapında öneme sahip olduğunu belirten Ragıp Kemal Bey, 1931 yılı itibariyle bu ovalardaki bataklıkların kurutulması ve arazinin 1slahı için on y1lda uygulanacak bir proje hazırlandığını bildirmiştir. Aktardığına göre, bu projenin uygulanması sonucunda Bursa'nın tarımsal üretiminin dört kat artırılması umuluyordu (R.K., Bursa, bir fabrikalar şehri halini aldı, 1931).

Muhabir Bursa'nın ekonomik etkinliklerini ve zenginliğini okuyucularına şöyle anlatmıştır:

"Meyva itibarile Bursa çok zengindir. Mahsulâtı arziyesi de Mütenevvi ve mebzüldür. Zeytin ve zeytin yağı ihracatı da çoktur. Meşhur Karaca Bey harası ve Uludağ havalisi ziyade mikdarda hayvan yetiştirmeğe müsaittir. Peynircilik ve yağcılık çok ilerlemiştir. M. Kemal Paşa ile Karaca Beyin peynir ve tere yağları pek meşhurdur. Bursanın bilhassa Kozacılığ 1 ve ipek mensucatı fevkalade şöhret bulmuş ve burası bir fabrikalar memleketi hâlini almıştır. Tabiatin bunca bahşayişlerine zamimeten Haliki Azam Bursaya şifalı kaplıcalar da ihsan buyurmuştur. $\mathrm{Bu}$ sayede hesapsız hastalar burada şifalar bulmakta ve hali sıhhatta olanlarda zevkıyap olmaktadırlar." (R.K., Bursa, bir fabrikalar şehri halini ald1, 1931)

Cumhuriyet öncesi dönemde üç tane harap fabrika ve on beş civarında tezgâhla yürütülen ipekli dokuma sektöründe 1931 yılı itibariyle fabrika sayısı 42'ye yükselmiş̧i (Kaya, 1999: 217). Ragıp Kemal Bey'in verdiği bilgiye göre aynı yılın başlarında Bursa'daki 473 dokuma tezgâhında günlük 1000 kiloya yakın ipek işleniyordu. Bu da yıllık 360.000 kilo ipek demekti. Bursa tek başına bu ihtiyacı karşılayamadığından çeşitli vilâyetlerdeki kozalar buraya getirilip satılıyordu (R.K., Bursa, bir fabrikalar şehri halini aldı, 1931). 
Ragıp Kemal Bey 1931 yazında bir kez daha Bursa'yı ziyaret ettiğinde ucuzluğun adeta "iptizal" hâlinde olduğunu görmüştür. Verdiği bilgiye göre kentte yüz patlıcan on kuruşa, karpuzun okkası kırk paraya, bamya yüz paraya, şeftali 10-30 kuruşa, domates kırk paraya, soğan yüz paraya sat1lıyordu (Ragip Kemal, Bursada yapılan yeni binalar, 1931). Bursa şehri kavun, karpuz, şeftali, sebze, meyve ile tıka basa dolmuştu. Karpuz tarlalarına arabasını yanaştıranlar bir lira karşıllğında karpuz ve kavun yükletip şehre getiriyordu. Her gün yüzlerce araba karpuz ve sebze kente geliyor, Yoğurtçu Hanında yok pahasına satılıyordu. Bir araba karpuz iki liraydı. Fiyatlar İstanbul ile kıyaslandığında müthiş düşüktü. Örneğin İstanbul'da yirmi beş kuruşa satılan karpuzlar Bursa'da beş kuruştu. Sebzeler adeta bedavaydı. Ragıp Kemal Bey sebze ve meyve fiyatlarındaki bu ucuzluğa rağmen lokantaların çok pahalı olduğunu belirtmiş bir tabak sebzenin on beş kuruşa, bir porsiyon karpuzun da on kuruşa verildiği söyleyerek “Biraz insaf lâzım değil mi?" deme gereğini duymuştur (Ragıp Kemal, Bursada yapılan yeni binalar, 1931).

Muhabir Bursa'daki sebze-meyve üretimi ve fiyatlarıla ilgili detaylı bilgiler verirken duyumlarına dayanarak İstanbul-Bursa arasındaki ticareti de mercek altına almış, İstanbul Belediyesi'nin dikkatini çekmiştir. Çünkü Tekirdağ, Bursa gibi İstanbul'a yakın vilâyetlerde sebze ve meyve bol ve ucuz olduğu hâlde İstanbul'da pahalı satıliyordu. Karpuz ticaretinden örnek veren Ragıp Kemal Bey'in aktardığına göre İstanbul'a dört mavna karpuz geldiği zaman kabzımallar ortadan kayboluyor ve bu mallara talip olmuyordu. Çaresiz kalan mal sahipleri de karpuzları nakliye ücreti karşılığında satıyor ve memleketlerine geri dönüyordu. Daha sonra da pek ucuza alınan bu karpuzlar İstanbul halkına pahalıya satılıyordu. Muhabire göre kavunkarpuzun en bol olduğu zamanda bile İstanbul halkının doya doya karpuz ve meyve yemesine meydan vermeyen bu insafsiz esnafa müdahale etmek gerekiyordu. Ayrıca Bursalılar da çok zarardaydı. İstanbul esnafı Bursa'dan aldığg ürünü pahalıya satıyor, bu da talebi azalttı̆̆ından yeni 
mala ihtiyaç duyulmuyordu. İstanbul esnafı az kâra razı olsa mallar daha çok satılacak, Bursa'da çürüyüp sokaklara atılmayacak, esnafın ve üreticinin yüzü gülecekti. Ragıp Kemal Bey’e göre İstanbul Belediyesi bu durumları göz önüne alarak tedbirler düşünmeli ve uygulamaya koymalıydı (Ragıp Kemal, Bursada yapılan yeni binalar, 1931).

Söz konusu yıllarda Bursa'da İş Bankası, Adapazarı Emniyet Bankası, Ziraat Bankası, Emlâk ve Eytam Bankası, Adapazarı Türk Ticaret Bankası ve Osmanlı Bankası'nın şubeleri bulunuyordu (Sedad, 1934: 4-8). Ancak Cantürk bunlardan yalnız biri hakkında duyumlarını aktarmış ve Ziraat Bankası şubesinin hizmetlerinden övgüyle söz edildiğini kaydetmiştir. 1932 yılında vilâyette bir kooperatif kurulmuş ve büyük çiftlik sahipleri de bu kooperatife katılmıştı. Bunun dişında 36 kooperatif daha kurulmuştu (Ragıp Kemal, Kaplıca şehrinde göze çarpan şeyler, 1932).

Gezi yazılarında Bursa'nın sebze ve meyveleriyle ilgili ayrıntılı bilgiler veren muhabir 1933 yılındaki gezisinde de yine aynı şeyi yapmış ve adeta ballandıra ballandıra gördüklerini anlatmıştır. Ragıp Kemal Bey'e göre Bursa'da meyve dükkânları adeta birer çiçek buketine benziyordu. Meyveler o kadar iştah açıcı şekilde sergileniyordu ki insanda karşılarına geçip seyretme isteği doğuyordu. Muhabirin ziyareti sırasında şeftali mevsimiydi ve şeftalilerin her cinsinde başka bir lezzet vardı. En nefis şeftaliler 20 kuruşayd1. Bir önceki yıl okkası yirmi para olan karpuzların okkası ise 1933'de 100-120 paraya (2,5-3 kuruş) yükselmişti (Ragıp Kemal, Bursanın kıymetli bir irfan müessesesi, 1933).

Bursa'nın yoğurt ve peynirleri de çok meşhurdu. Bunların âdeta kaymaktan farkı yoktu. Ancak bu kadar sebze ve meyve bolluğuna rağmen Bursa'daki lokantalarda yemekler hâlâ çok pahalıydı. Örneğin bir etli sebze yemeği 15 kuruştu. Bu yemeğin içindeki etler de kırpıntı ve kakırdak türü şeylerdi. Çekirge tarafında ise her şey pahalıydı. Muhabir 
gördükleri karşısında "Burada bazı esnaf, gelenleri âdeta milyoner zannediyor. $\mathrm{Bu}$ zihniyeti bırakmak lâzımdır" demekten kendini alamamışırı (Ragıp Kemal, Bursanın kıymetli bir irfan müessesesi, 1933).

Ragıp Kemal Bey, Bursa'daki merinos koyun yetiştiriciliğini de mercek altına almayı ihmal etmemiş, 1932 kışındaki gezi yazısının önemli bir kısmını bu konuya ayırmıştır. Ülkede yetiştirilen koyunlar içerisinde en faydalısının merinos cinsi koyunlar olduğunu belirten muhabir, bunun merinos koyununun yünündeki elastikiyet, incelik ve kıvırcıklıktan kaynaklandığını anlatmış, bu hayvanın yününden yapılan dokumaların bu sebeplerle daha pahalı olduğunu aktarmıştır. Verdiği bilgiye göre Bursa'da koyunculuğun korunması, geliştirilmesi ve özellikle de merinos cinsinin sslah edilmesi ve çoğaltılması amacıyla kurulmuş olan cemiyet 1932 yılı itibariyle büyük bir şevkle çalışıyordu. Baytar Müdürü tarafından kendisine gösterilen yarım kan olarak yetiştirilmiş olan merinosların yünlerini inceleyen muhabir, aldığ 1 bilgiler 1şı̆̆ında ülkenin refah ve zenginliği için önem arz eden bu hayvanların yetiştirilmesinin Bursa'da en önemli gündem maddesi olduğu kanaatine varmıştır. Cemiyetin karşılaştığı zorluk ve engelleri sıralayan Ragıp Kemal Bey, "herkes" adına, şu konularda İktisat Vekâleti'nin dikkatini çekmiş ve çözülmesini rica etmiştir:

1- O yıl merinoslardan alınan yapağılar millî fabrikalar tarafından değer fiyatlarıyla alınmadığından merinos sahipleri üzülmüş ve "Mademki bu yünlerin öbür yünlerden fiyat farkı yoktur neden bunlarla uğraşalım?" demişti. Bu durum üreticinin şevkini kırıyor ve Bursa için zarara sebep oluyordu.

2- Bankaların hayvanlar üzerinden de kredi vermesi gerekiyordu. Oysa arazi ve emlak karşıllğında kredi veren bankalar hayvanları teminat olarak görmüyor, kredi alamayan koyun sahipleri zorlanıyordu. 
3- İstanbul'da mezbaha vergilerinin yüksekliği de yetiştiricileri baltalıyordu. Mal sahibi bir koyunu altı liraya sattığı hâlde eline geçen para ancak üç lirayd1.

4- Ulaşım tarifelerinin yüksekliği sebebiyle koyunların trenlerle sevkine imkân yoktu ve mal sahipleri bundan dolayı çok zarar ediyordu. Yetiştiricilerin desteklenmesi için demiryolu tarifelerinde önemli bir indirime ihtiyaç vardı (Ragıp Kemal, Bursadaki merinoslar nasıl ıslah ediliyor?, 1932).

Yaklaşık bir buçuk yıl sonra bu konuda yeni bilgiler veren Cantürk, büyük beklentilerle açılmış olan Koyunculuk Cemiyeti'nin dağılmış olduğunu ancak yeni Baytar Müdürü Tahsin Nahit Bey'in bu cemiyeti tekrar canlandırmaya azmettiğini bildirmiştir. Ayrıca merinos cinsinin çoğaltılması ve korunması için tedbirler alınmış, vilâyette yetiştirilmiş olan 1500 koç üreticilere dağıtmıştı (Ragıp Kemal, Bursa vilâyetinde hayvan hastalıklarile mücadele, 1933).

Muhabir 1934 y1lındaki gezisinde kentteki en önemli sanayi tesislerinden biri olan İpek İş Fabrikasını ziyaret etmiş, izlenimlerini Vakit gazetesinde okuyucularına aktarmıştır. Bu fabrika İş Bankası'nın sanayi alanındaki iştiraklerinden biriydi (Türkiye İş̧ Bankasının On Y1lı, 1934: [88]). Kentte dokunan ipekli kumaşlar ile hamam takımları ve pamuklu mensucatın geçmişten beri Bursa'ya şöhret kazandırdığını hatırlatan Ragıp Kemal Bey ipek kumaşların "Bursa'nın göz kamaştırıcı varlıklarından birisi" olduğunu belirtmiştir. İpek ve dokuma sanayii sayesinde şehre yüklü miktarda para giriyor ve pek çok fakir aile geçimini bu yolla sağlyyordu. Muhabirin verdiği bilgiye göre mevcut ipek fabrikaları içerisinde özellikle bu fabrikanın ürünleri görülmeye değerdi (Ragıp Kemal, Bursada İpekliler, 1934).

İpek İş Fabrikasının temeli 1925 yılında Atatürk tarafindan atılmıştı ve bir Türk anonim şirketi tarafından yönetiliyordu. Şirketin başında bankacılıktan gelen Rüştü Bey bulunuyordu. Apre dairesindeki 
Alman şefin dışındaki tüm uzmanlar Türk'tü. Fabrikanın makineleri son sistemdi. Türkiye'deki fabrikalar içerisinde en çok tür kumaşı bu fabrika üretiyordu. Kumaşların kalınlığı ve güzelliği Avrupa ayarındaydı.

Fabrikanın müdürü Fehmi Bey ile Mühendis İhsan Bey'in eşliğinde fabrikanın her tarafını gezen muhabir gördükleri karşısında hayran kalmıştır. Fabrikanın bir kapısından girip diğer kapısına ulaşmaları bir saat sürmüş, muhabir gezi sırasında kendi ifadesiyle kan ter içinde kalmıştır. Gezi boyunca hare yapan, kumaş yumuşatan makineleri, germe ve ütü işlemlerini, alev makinesini, boyahaneyi, şarp makinelerini, Şemsa Hanım'ın yönetimindeki kimyahaneyi, boya ustası Hakkı Efendi'nin işlerini, ihzar dairesini, apre dairesini, permutit su tasfiye cihazını görme şansı olmuştu. Fabrikada birçok erkek ve kız işine odaklanmış şekilde çalışıyor, mühendis ve uzmanlar sağa sola koşuyordu. Bir başka bölümde ise toplar hâline getirilmiş olan kumaşlar ambajlanıyor ve İstanbul'a gönderiliyordu (Ragıp Kemal, Bursada İpekliler, 1934).

\section{Sosyal ve Gündelik Yaşam}

1930'lu yılların ilk yarısında Türkiye'nin genelinde sosyal ve gündelik yaşamda hızlı değişim ve dönüşümler yaşanmıştır. Osmanlı İmparatorluğu'nun sonunu getiren savaşlar silsilesinden yorgun çıkan toplum 1920'li yıllarda yaralarını kısmen sarabilmiş, aynı süreçte Cumhuriyet rejiminin sosyal yaşama getirdiği değişim gündelik hayata yansımaya başlamıştır. Kadınların sosyal yaşama katılması, millî bayram kutlamaları ve halkevleri bunun en somut göstergeleridir. Öte yandan yerel yönetimlerin yanı sıra özel girişimcilerin kent yaşamına yeni kazandırdığı tesisler halk için yeni birer çekim merkezi olmuş, "yedinci sanat" olarak insanoğlunun hayatına giren sinema da hem yeni bir sosyal faaliyet alanı olarak gündelik hayatın bir parçası olmuş hem de insanlar arasındaki etkileşimi hızlandırmıştır. 
Aynı yıllarda Bursa'da da canlı bir sosyal ve gündelik hayat söz konusudur. Cumhuriyet rejimiyle birlikte artan iletişim ve ulaşım olanakları, kent dokusundaki değişim özellikle Tayyare Sineması ile Bursa Halkevi'nin faaliyete başlaması ve milli bayram kutlamaları Bursa'da gündelik yaşamı canlandırmıştır (Bilgi, 2006: 131-132). Örneğin 1932-1934 yıllarında Halkevi'nde 4 tane piyes, 38 tane de temsil sergilenmiş, bu etkinlikleri 22.150 kişi izlemiştir (Aladağ, 2004: 72).

Bursa'daki sosyal ve gündelik yaşamla ilgili Ragıp Kemal Bey'in üzerinde en çok durduğu konular park ve bahçeler ile yemek kültürü olmuştur. 1931 yılında Tayyare Cemiyeti'nin sinema binasının anıt gibi yükselmesini övgüye değer bulmuş ayrıca belediye dairesinin âtıl ve metrûk bahçesinin güzel bir park hâline getirilmiş olduğunu haber vermiştir. Bildirdiğine göre bu parka orkestra ve ince sazlar konmuştu. Hamdi Emin Bey tarafından işletilen eski İktisat Müdüriyeti binası da düzenlenmiş ve sinema hâline getirilmişti. Bahçesinde varyete ve sinema oynatılıyordu (Ragıp Kemal, Bursada yapılan yeni binalar, 1931).

Ragıp Kemal Bey 1934 yılındaki gezisinde kentteki gündelik hayata daha ayrıntılı değinmiştir. Verdiği bilgilere göre Bursa' da herkes sabahtan işine koşuyor, öğle vakti kentte bir tenhalık oluyordu. İkindi saatlerine doğru halkın bir kısmı Setbaşı'ndaki Şaban Bahçesine, bir kısmı Belediye Bahçesindeki saza, bir kısmı da Tophane Bahçesine gidiyordu. Bazılarının tercihi ise kaplıcalar oluyordu. Özellikle Belediye Bahçesindeki saz çok rağbet görüyordu. Daha sakin zaman geçirmek isteyenler ise Hükümet Konağı'nın karşısındaki kahvehanelere, Setbaşı'ndaki gazinolara, Türk Ocağı gazinosuna veya Yeşil Cami tarafındaki kır kahvelerine yöneliyordu. Cuma günlerinin gözde yerleri Uludağ ve Mudanya idi (Ragıp Kemal, Bursada İpekliler, 1934).

Bursa'nın nefis şeftalileri sabahları halde 10 kuruşa satılıyordu. Yemişçi dükkânlarındaki satış fiyatı ise 20-25 kuruştu. Yine halde 5 kuruşa satılan armutlar sokak başlarında 7,5 kuruşa, kilosu 20 para olan 
karpuzlar ise sokaklarda iki kuruşa satılıyordu. Kentte birkaç lokanta açılmıştı. Yemekler lezzetli ve ucuzdu. Belediyenin Belediye Bahçesi'nde başlattığı tabldot yemek servisi 35 kuruştu. Kentteki kebaplar da çok meşhurdu ve özellikle İskender Usta'nın kebapları çok rağbet görüyordu (Ragıp Kemal, Bursada İpekliler, 1934).

Gezdiği yerlerde her zaman olmasa da halkevlerini ziyaret eden, etkinlikleri hakkında bilgi veren muhabir ne yazık ki 19 Şubat 1932 tarihinden itibaren faaliyete başlayan ve Bursa'nın sosyal yaşamında önemli bir yeri olan Bursa Halkevi'ne dair herhangi bir bilgi paylaşmamıştır. Bununla birlikte Bursa'daki gündelik hayata ilişkin paylaştı̆̆ sıra dışı bir konu vardır. Muhabir 1933 yılındaki ziyareti sırasında yılanlarla gösteri yapan iki kişiyle görüşmüş ve bunlardan yılanlar hakkında bilgi alarak okuyucularıyla paylaşmıştır (Ragıp Kemal, Bursa ve Mudanyada yılan avcıları, 1933).

Muhabirin verdiği bilgiye göre yılan ticaretiyle uğraşan bazı kişiler yakaladıkları yılanları Avrupa'ya gönderene kadar bunları büyük şehirlerde halka teşhir ediyor, böylece yol parasını ve gerekli masrafları çıkarıyordu. İkisi Mudanya'da ikisi de Bursa'da olmak üzere dört yılan avcısıyla karşılaşan muhabir, Bursa'da her ikisi de İbrahim adındaki yılan avcılarının belediye karşısında kiraladıkları dükkâna konuk olmuştur. Yılan avcıları dükkânda yılanları vücutlarına sararak ve ağızlarına alarak gösteri yapıyordu. Bu yılanların büyüyen türleri 30 kilo ağırlığı aşabiliyor, üç metre uzunluğa erişebiliyordu. Bir başka tür de bilekten ince ve iki metre uzunluğundaydı. Bakla Damga türündeki engerek yılanları oldukça zehirliydi. Sarı benekli Çakırdağ Alacası türündeki engerekler ise Edremit'in Kazdağı'nda, Akhisar'ın Gedevre Dağı'nda ve İzmir'in Naldöken Dağları'nda bulunuyordu. Bu yılanlar ancak arkalarından yetişilerek iki el ile baş ve kuyruk taraflarından tutularak yakalanabiliyor, yakalandıktan bir hafta sonra zararsız hâle getirilebiliyordu. 


\section{Turizm ve Tanıtım Faaliyetleri}

Ragıp Kemal Cantürk gezi yazılarında Bursa'nın turistik özelliklerine ve kentteki turizm faaliyetlerine geniş yer ayırmıştır. Verdiği bilgilere göre Bursa da tıpkı İzmir gibi gelen gidenin çok olduğu bir kentti. Ancak İzmir'e geliş gidişler ticari amaçlı olduğu hâlde Bursa'y1 ziyaret edenlerin çoğunluğu şifa arayan hastalar ile zevkine düşkün kişilerdi. Özellikle de yaz aylarında Bursa mahşeri bir hâl alıyordu (Ragıp Kemal, Bursada hararetli bir belediye faaliyeti var, 1934). Kent gerek sağlik turizmi, gerek ucuzluğu gerekse de tarihi değerleri ve doğal güzellikleri açısından adeta bir cennetti (Ragıp Kemal, Bursa bir sene içinde çok değişti, 1933).

1931 yllındaki ikinci ziyaretinden itibaren Bursa'daki turizm hakkında ayrıntılı bilgiler veren muhabirin anlattıklarına göre Bursa, turizm potansiyelini erkenden değerlendirmeye başlayan ve bu konuda Türkiye'ye öncülük eden şehirlerden biri olmuştur.

Muhabir 1931 Eylül'ünde yayımlanan mektubunda, önceden Bursalıların çadır kurup on beş gün süreyle yiyip içtiği, soğuk subaşlarında âlemler yaptığı ve kilo alarak geri döndüğ̈̈ yaylaya bir dağ oteli inşa edildiğini bildirmiştir. Verdiği bilgiye göre otel, Bursa için bir onur kaynağıydı ve Bursa'nın doğal güzellikleri bu eserle tamamlanmıştı. Muhabire göre "Vakti ve hali müsait olup ta bu otelde on beş gün kadar vakit geçirmeyenler hayatta büyük bir firsatı kaybetmiş olurlar!"d1 (Ragip Kemal, Bursada yapılan yeni binalar, 1931).

Bursa'nın özellikle sonbaharda çok güzel ve çekici olduğunu belirten muhabir, 1931'in sonbahar günlerinde kentin ziyaretçilerle dolu olduğunu ve otellerde neredeyse yatacak yer kalmadığını bildirmiştir. Verdiği bilgiye göre Bursa'ya gösterilen yoğun ilginin başlıca sebepleri hem Yalova ve hem de Mudanya üzerinden ulaşım kolaylığı, özellikle yiyecek fiyatlarındaki uygunluk ve Bursa halkının misafirperverliğiydi. Özellikle, yeni açılan Uludağ oteli herkesin merakını uyandırıyor ve pek 
çok kişiyi cezbediyordu. Yüzyıllardır ıssız olan karlı dağlar insanların kahkahalarıyla şenleniyordu (Ragıp Kemal, Bursaya rağbet, 1931).

Muhabirin verdiği bilgiye göre turizmin gelişmesi için 1931 yılında önemli bir adım atılmış, Belediye Başkanı Muhittin Bey'in başkanlığında, Türkiye Turing ve Otomobil Kulübü'nün Bursa Şubesi açılmıştı. Henüz açılalı üç ay olmasına rağmen, şube önemli işler görmeye başlamıştı. Amaç Bursa'ya turist getirmekti ${ }^{11}$. Muhittin Bey, yabancı dil bilen ve Avrupa'yı gezmiş bir kişi olduğu için herkes onun başarılı olacağı konusunda hemfikirdi. Şubenin diğer üyeleri de memleketi tanıyan ve çağdaş hayatın gereklerine uygun uzmanlıkları bulunan kişilerden oluşmuştu. Bunlar Doktor Osman Şevki, Müze Müdürü Mahmut, Ticaret Odası'ndan Tayyar, tüccardan İsmail Hakkı ve Osman Beylerdi (Ragıp Kemal, Bursaya rağbet, 1931).

Kulübün Bursa Şubesi bir yandan kuruluşunu tamamlarken diğer yandan bir rehberin basımı için hazırlıklara girişmişti. Oteller, banyolar (kaplıcalar) ve bazı sinemalar ile lokantalar Turing Kulübü üyesi olan kişilere önemli indirimler yapmıştı. Kulübe girebilmenin şartı iki üyenin referansı ile senelik üç lira aidat ödemekti.

Kulüp 1932'nin bahar aylarında kuruluşunu tamamlayacak ve tam olarak faaliyete başlayacaktı. Böylece Bursa'nın o zamana kadar yeterince tanınmayan güzellikleri ve faydalı yerleri ziyaretçilerin beğenisine sunulacaktı. Başkan Muhittin Bey bütün bu işleri özel bir ilgi ve zevkle takip ediyor, en küçük ayrıntıyla dahi ilgileniyordu. Bursa'nın merkezinde kalacak ziyaretçilerin konforlu, güvenli ve huzurlu şekilde konaklayabilmesi için her türlü çaba sarf ediliyordu. Banyolara (kaplıcalara) gidecek kişilerin elektrikle tedavisi ve hangi banyoları kullanması gerektiğinin belirlenmesi için, ünlü bir uzman olan Dr.

\footnotetext{
${ }^{11} \mathrm{O}$ dönemin tabirine bağlı olarak orijinal metinde "turist" değil "seyyah" kelimesi kullanılmıştır.
} 
Nüzhet Şakir Bey daima görev başındaydı. Paris Hidroloji ve Klimatoloji Enstitüsü mezunu olan Nüzhet Şakir Bey operatör ve fizyoterapi uzmanıyd1. Bu sevecen doktor fakirleri ücretsiz muayene ettiği gibi gerekenlerin ilaç parasını da kendisi karşılıyordu.

Şube faaliyetlerine başlamış olup üyelik başvurularının hepsini olumlu cevaplandiriyordu. Turing Kulüp belgesi bulunan turistlere düzenli programlar hazırlanıyor yalnız Bursa vilâyeti içerisinde değil Balıkesir, Eskişehir, Afyonkarahisar, Kütahya ve Konya vilâyetlerine de özel rehberler eşliğinde turlar düzenleniyordu.

Şubenin yayın kısmında Bursa'yı iyi tanıyan kişilerden Dr. Osman Şevki ve Tevfik Beyler ile Müze Müdürü Mahmut Bey ve Şevket Efendi görevliydi. Bu komisyon vilâyetin anıtsal eserlerini inceleyerek Bursa hakkında ayrıntılı ve değerli bir eser yayımlamak üzereydi. Kent bu bakımdan "Beldelerin Melikesi” İstanbul'dan öndeydi ${ }^{12}$.

Turing Kulübü Bursa Şubesi yurtdışından turist getirmek için de bağlantılar kurmaya başlamıştı. Almanya'da 132.000 otomobil ve motosiklet sahibinin üyesi bulunduğu Adak adlı ünlü bir kulübün temsilcisi Her Aleksandr Gerdeysen, Bursa'ya turist getirmek için birkaç gün önce kente gelmiş ve Belediye Başkanı ile görüşmüştü. Planlanana göre bu kulübün üyeleri Köstence'ye kadar otomobilleriyle gelecek ve oradan vapura binecekti. Bu durumda 1932'nin ilkbaharında Bursa'nın turist akınına uğrayacağı muhakkaktı. Yine kısa süre önce Fransız Ayan Meclisi İkinci Başkanı Mösyö Radiye ile beraberindeki milletvekillerinin Bursa'ya gelmesi kentin tanıtımı için iyi bir firsat olmuştu. Heyet özel

\footnotetext{
${ }^{12}$ Nitekim Ragip Kemal Bey bu bilgileri verdikten sonra "Beldelerin Melikesi” dediği İstanbul için hâlâ böyle bir turistik rehber yazılmamış olduğunun ve bunun zararlarının görüldüğünün altını çizmiştir. Zira muhabirin verdiği bilgiye göre Bulgaristan'a seyahat ettiğinde oradakiler kendisine böyle bir rehber olup olmadığını sormuş ve Bulgaristan'dakilerin İstanbul'a gelmek için böyle bir rehbere ihtiyaç duyduğunu bizzat görmüştür (Bursaya rağbet!, 1931).
} 
olarak ağırlanmış ve konuklar kendilerine gösterilen misafirperverlikten çok memnun kalmıştı (R.K., Bursalıların dertleri, 1931).

Ragıp Kemal Bey 1932 yılının sonbaharında Bursa kent merkezine yaptığı geziye dair yazdığı mektubunun büyük bir bölümünü de kentteki otel ve kaplıcalar ile Uludağ'a yaptığı seyahate ayırmıştır (Ragıp Kemal, Kaplıca şehrinde göze çarpan şeyler, 1932).

Muhabire göre Bursa'da en çok gidilen yerlerin başında kaplıcalar geliyordu. Ancak buraya ulaşımda ciddi sıkıntılar vardı. Mevcut otobüsler ihtiyaca yeterli gelmediği gibi düzensiz işlediği için de insanlar saatlerce duraklarda bekliyordu. Üstelik belediyenin seferleri düzenlemek için yaptığ 1 yeni tarife düzensizliği daha da artırmıştı. Çünkü belediye şehir dışına işleyen otobüslerin kaplıcalara sefer yapmasını yasaklamış ve rekabet ortadan kalkmıştı.

1932 yazında 60 üyesi olan "Bursa Çekirge Otel ve Hancılar Cemiyeti" faaliyete başlamış, başkanlığına Çekirge Palas müsteciri Hüseyin Bey seçilmişti. Çekirge'de 21 kaplıca açılmıştı. Bunların beşinde yemek ve birisinde de saz vardı. Aileleriyle gelenlere ve uzun süre kalanlara önemli indirimler yapılıyordu. Ancak Ragıp Kemal Bey'in verdiği bilgilere göre 1932'nin Eylül ayı itibariyle Bursa'daki otelciler hâllerinden memnun değildi. Otelciler ile kaplıcalar yeterli müşteri olmaması sebebiyle fiyatlarda dikkate değer indirimler yapmıştı ve müthiş bir ucuzluk söz konusuydu. Örneğin birinci sinıf otellerde kahvaltı ve yemek dâhil olduğu hâlde tek yatak iki lira, çift yatak bir buçuk liraydı. Kaplicalarda ise standart fiyatlar yoktu. Kaplica işletmecileri pazarlıkla kazanacakları her kuruşa razı oluyordu.

Otelciler belediyenin su konusundaki uygulamasından şikâyetçiydi. Zira belediye suyun tonu için şehir içindeki hamamlardan beş, fabrikalardan da üç kuruş aldığı hâlde otel ve kaplıcalardan onar kuruş alıyordu. Otelciler bu konuda destek göremediklerini ve kimsesiz 
kaldıklarını hissediyordu (Ragıp Kemal, Kaplıca şehrinde göze çarpan şeyler, 1932).

Ragip Kemal Bey bu ziyareti sirasinda Otelciler Cemiyeti'nin davetlisi olarak yirmi kişinin üzerindeki bir kafile ile Uludağ'a seyahat etmiştir. Çok sıcak ve boğucu bir havanın hüküm sürdüğü Bursa'dan ayrılan kafile yükseldikçe manzarası değişen bir yolda iki saat süren bir yolculuk yapmıştır. Bu süre içerisinde jeolojik oluşumlar, çam ağaçları ve kızıl otlar birbirini izlemiştir. Çamlıklarda aile çadırları, dumanı tüten ocak ve kebaplar ile buz gibi suların yakınından geçen kafile iki saatin sonunda 1850 rakımda yer alan meşhur otele ulaşmıştır. Bursa'da hava sıcaklığı 34 derece iken burada 14 derece olduğu için kafiledekiler gelir gelmez üşümüş ve soba yaktırmak zorunda kalmıştır.

Uludağ'ın yükseklerinde yer alan meşhur otel Hususi Muhasebe'ye aitti (Sedad, 1934: 38). Son sistem mefruşatla döşenmiş konforlu, şık ve şirin bir tesisti. 15 odası, 30 yatağı, birer salon ve banyosu, radyosu ile gramofonu vardı. Her odada su ve elektrik bulunuyordu. Otelin arkasında henüz erimemiş karlarla kaplı dağlar, önünde çam ağaçlarıyla yükselmiş tepeler vardı. İnsanın, otelin yanı başında akan suyun içine elini sokup kırk saniye kadar beklemesi bile çok zordu. Ne var ki Ragip Kemal Bey, otelin bulunduğu yeri beğenmemiş, kulağına gelen eleştirilere hak vermiştir. Ona göre de otelin bulunduğu yerde hayattan eser yoktu. Tabiat buraya cömertlik etmemişti. Bu kadar güzel bir otelin Bursa'ya hâkim, manzarası güzel, çamlık bir nokta yerine Bursa'dan uzak, ulaşımı zor ve masraflı, çorak bir çukurda yapılmış olması otelin müşterisiz kalmasına neden oluyordu. Bu yüzden de otelin konumu eleştiri konusuydu (Ragıp Kemal, Kaplıca şehrinde göze çarpan şeyler, 1932).

1933 yılının yaz sonu-sonbahar başlangıcında bir kez daha kenti ziyaret eden Ragıp Kemal Bey, Bursa'nın en kalabalık mevsimine denk gelmişti. Bursa' da büyük bir yoğunluk göze çarpıyordu. Oteller tıka basa 
dolmuş ve boş yer kalmamıştı. Turing Kulüp'ün Bursa Şubesi ve özellikle de Belediye Başkanı Muhiddin Bey ile arkadaşlarının takdire şayan çalışmaları meyvesini vermiş ve Bursa'nın her tarafı insan akınına uğramıştı. Gerek şehirdeki oteller gerekse de Çekirge'deki hamamlarda (kaplıcalarda) yer kalmamış ve sahiplerinin yüzleri gülmüştü. Uludağ'ın meşhur otelinde de misafirler vardı ve orası da çok rağbet görüyordu (Ragıp Kemal, Bursa bir sene içinde çok değişti, 1933). Çoğunluğu eğlenmek ve hoşça vakit geçirmek üzere kente gelen bu kalabalığın içerisinde her sınıftan insan vardı. Kaplıca sefaları, Uludağ gezileri, çalgılı bahçeleri, barları ve birçok eğlence yerleri yaz tatilini zevkle geçirmek isteyen pek çok kişiyi Bursa'ya toplamış, şehir adeta panayır hâlini almıştı. Kentin meşhur meyveleri ile yiyecek ve içecek konusunda her yerden ucuz olması bu ziyaretçi akınını artırıyordu (Ragıp Kemal, Bursa bu sene çok kalabalık ve eğlenceli, 1933).

Bursa son zamanlarda devlet erkânından da pek çok ziyaretçiyi ağırlamıştı. Bunlar arasında TBMM Başkanı Kâzım (Özalp) Paşa, Genelkurmay Başkanı Mareşal Fevzi (Çakmak) Paşa, Müfettiş Ali Sait ve Kolordu Kumandanı Ali Hikmet Paşalar ile Erzurum Milletvekili Aziz, Balıkesir Milletvekili Enver, Osman Hayri ve Afyon Milletvekili Haydar Beyler de bulunuyordu. Nüfus Genel Müdürü Galip Bey ile eski milletvekili ve Ziraat Bankası Umumî Meclisi üyesi Sabit Bey de Bursa'ya misafir olan yüzlerce tanıdık simadan bazılarıydı (Ragıp Kemal, Bursa bir sene içinde çok değişti, 1933).

Bursa'daki kalabalığa rağmen ziyaretçiler arasında yabancı ülke vatandaşlarının son derece az olması Ragıp Kemal Bey'in dikkatini çekmişti (Ragıp Kemal, Bursa bu sene çok kalabalık ve eğlenceli, 1933). İstatistikler de muhabirin bu kanısını doğrulamaktadır. Nitekim 1933'ün ikinci altı ayında otellere 4669 yolcu gelmişti. Aynı dönemde şehre gelen yabanc1 turist sayısı ise 239'du (Sedad, 1934: 27). Muhabir bir şehre gelecek turistlerden beklenen faydanın ancak onların kentte birkaç gün kalmalarıyla sağlanabileceğini, günübirlik ziyaretçilerden sağlanacak 
faydanın önemsiz olduğunu belirttikten sonra Bursa'ya yabancı turist çekmenin yollarını şöyle sıralıyordu:

1- Öncelikle Yalova ve Mudanya yolları çok iyi bir hâle sokulmaliydı.

2- Çekirge semtinde büyük ve mükemmel bir otel yapılmalıydı.

3- Ulaşım ücretlerinde son haddine kadar indirim yapılmalıydı.

4- Turistlerin pasaport ve kimlik kontrolleri onları sıkmadan, bunaltmadan yapılmaliydı.

5- Dünyanın her tarafında en iyi şekilde tanıtım ve propaganda yapılmaliydi.

Bursa'da birçok otelin yanı sıra kaplıcalarda da konaklama imkânı vardı. Ancak şehrin ihtiyacı her yıl artmakta olduğundan bu tesisler ihtiyacı karşılamaya yetmiyordu. Öte yandan kafile hâlinde gelecek turistleri de tek bir otele yerleştirme imkânı yoktu. Bu yüzden belediye 200 yataklı ve her türlü konfora sahip yeni bir otelin yapımına başlayacaktı. Muhabir bu haberi sevinçle karşılamış ve girişimi yerinde bulmuştur (Ragıp Kemal, Bursa bu sene çok kalabalık ve eğlenceli, 1933).

Ragıp Kemal Bey'in 1933 yılında Bursa'ya dair verdiği bilgilerden biri de kentte bir "Dağ Sporları Kulübü"nün kurulmuş olduğudur (Kemal Ragıp, Bursada dağ sporları çok rağbet görüyor, 1933). Muhabirin aktardığına göre bu yeni kuruluşun amacı gençliği dağ sporlarına alıştırmaktı. Uzmanlara göre Uludağ yöresi dağ sporlarına son derece elverişliydi. Bu sporlar kışın yapılıyor yaz aylarında da seyahatler düzenleniyordu.

Kulüp üyelerinin tümü sivil vatandaşlardan oluşuyordu. Ancak bunların idaresi ve bilimsel yöntemlerle eğitilmesi için ordu tarafından Miralay İsmail Hakkı Bey görevlendirilmişti. İsmail Hakkı Bey 
Muğla'da Dağ Alayı kumandanlığında, eşkıya takiplerinde ve Ağrı harekâtında bulunmuş değerli bir komutandı.

Gelecek kış aylarında alıştırmalara devam edebilmek için Uludağ'da önemli düzenlemeler yapılmıştı. 18. kilometreden, otelin bulunduğu 34. kilometreye kadar altı "imdat evi"nin yapılmasına başlanmış ve bir kısmı tamamlanmıştı. Bunlardan birisi küçük bir okul olarak kullanılabilecek durumdaydı ve 1.700 liraya mâl olacaktı. Diğerleri de kafilelerin tipi vb. durumlarda sığınabilmeleri içindi. Kışın bu "imdat evleri" ile otel arasında kızak işletme fikri de söz konusuydu. Böylece kayak yapanların kızakla otele gidebilmelerine imkân sağlanacaktı.

22. kilometreden otele kadar elli metrede bir ve otelden de dağın 2.550 metre rakımındaki zirvesine kadar yüz metrede bir olmak üzere her birisi 6-8 metre uzunluğunda işaret direkleri dikilmişti. Kışın çok fazla kar yağdığında yollar kapandığından bu işaretler sayesinde yol bulmak mümkün olacaktı.

Kulüp tarafindan yüz kadar kayak tedarik edilmek üzereydi. Bir önceki kış kulüp üyelerinden on beşi kayak edinebilmişti. Bunlar yirmişer liraya Almanya'dan getirilmişti. Bursa'daki Sanayi Mektebi ise bu kayakları daha ucuza imal edecekti. Fakat bunun için damarsız, $15 \mathrm{~cm}$ çapında ve özel olarak yetiştirilmiş dişbudak ağaçları gerekiyordu. Karacabeyli Nuri Bey kendi çiftliğindeki işe yarar dişbudakların ücretsiz kesilmesine izin vermiş ve bu cömertliği ile takdir toplamıştı. Kayaklarla beraber bir miktar dağ levazımı da tedarik edilecekti. Spor Federasyonu Başkanı ve Erzurum Mebusu Aziz Bey bu kulübe azamî derecede yardım ediyordu.

Yüzeysel bakıldığında sadece turizm ve spor amaçlı görünen dağcılığın aslında paramiliter bir yönünün de bulunduğu Ragıp Kemal Bey'in açıklamalarından anlaşılmaktadır. Nitekim dağcılığın sağlıklı bir yaşam için önemini dile getiren ve bu konuda teşvik edici sözler söyleyen 
muhabirin verdiği bilgiye göre dağcılık sporunun başlangıcı I. Dünya Savaşı yıllarına dayanıyordu. $\mathrm{Bu}$ savaş sırasında dağlarda çetin muharebeler yaşanmış ve bütün ordular dağ levazımıyla kendilerini donatmaya mecbur kalmıştı. 1930’lu yıllarda ise Avrupa devletleri dağ alayları değil, dağ kolorduları kuruyordu. Ragıp Kemal Bey'e göre Türkiye de dağlık bir coğrafyada olduğundan bu teşkilâta önem verilmesi gerekiyordu.

Yeni bir dünya savaşının gündemde olduğu 1930’lu yıllarda Bursa'da bir yandan paramiliter dağcılık faaliyetleriyle olası savaşa hazırlık yapılırken öte yandan sivil savunma eğitimleri de veriliyordu. Nitekim Miralay İsmail Hakkı Bey zehirli gazlar ile hava savaşları hakkında Bursa'da önemli konferanslar vermişti. Bunlardan korunma yollarını ve çok pratik önlemleri göstermişti. Bu konferansların notları iki yüz sayfalık bir kitap hâlinde yayınlanacaktı. Muhabire göre her vatandaş gelecekteki savaşlarda zehirli gaz ve bombalardan nasıl korunacağını öğrenmek zorundaydı. Zira Avrupa devletlerinin büyük masraflar yaparak bu tür savaşlara hazırlandığı her gün gazetelere yansıyordu (Kemal Ragıp, Bursada dağ sporları çok rağbet görüyor, 1933).

Ragıp Kemal Bey’in 1933 yılındaki gezisinden kısa süre sonra Bursa Belediyesi turizm konusunda önemli bir adım daha atmış, 29 Ekim 1933 'te belediye bünyesine "Seyyahin Şubesi”ni kurmuştur. Bu şubenin görevi kente gelen yabancı ve yerli turistlere kenti tanıtmak, tarihi ve bilimsel bilgi sunmaktı. İstanbul Belediyesi Seyyahin Şubesi ile ortak bir program yürüten bu şube Avrupa'dan turist getirmek için tanıtım faaliyetlerine başlamıştı. Bu amaçla renkli büyük afişler ve broşürler bastırılarak Avrupa'daki otel ve acentelere gönderilmiş, gazetelerde Bursa ile ilgili tanıtım yazıları çıkması sağlanmıştı (Sedad, 1934: 26).

Cantürk 1934 yılındaki gezisinde de kentteki turizmin görünümüne değinmeyi ihmal etmemiş, kaplıcaları ve emsalsiz 
meyveleriyle zaten bir çekim merkezi olan Bursa'nın son yıllarda gerçekleşen olumlu değişikliklerle turistik açıdan daha da önem kazandığını kaydetmiştir. Bursa'nın gün geçtikçe güzelleşmesi, her tarafa ulaşım vasıtalarının bulunabilmesi hastaların yanı sıra sağlıklı kişileri de Bursa'ya çekiyordu. Ayrıca belediyenin aldığı ciddi tedbirler sayesinde oteller 1slah edilmiş, misafirlerin ihtiyaçları en üst düzeyde sağlanmıştı. Buna bağlı olarak kaplıcalara olan ilgi bir önceki yıla göre artmıştı (Ragıp Kemal, Bursa ovasındaki sulama ve kurutma ameliyatı, 1934). Gerçekten de Bursa turizm konusunda kısa sürede iyi yol kat etmiş, bu durum kente gelen turist nitelik ve niceliğinde olumlu bir değişime yol açmıştı. Nitekim 1934 yılı içerisinde Bursa'ya 300-400 kişilik gruplar hâlinde turist akını yaşanmıştı. Aynı yıl 900'ü aşkın Fransız ve Polonyalı turist de kenti ziyaret edenler arasındaydı (Sedad, 1934: 27-28).

\section{Millî Mücadele Kahramanları}

Gezip gördüğ̈̈ yerlerin Millî Mücadele yıllarındaki olaylarına ve kahramanlarına değinmeyi âdet hâline getirmiş olan muhabir bu bağlamda Bursa'da üç kişiden söz etmiştir. Bunlardan ilki sonraki yıllarda Bursa Belediye Başkan Yardımcılı̆̆ı görevini üstenecek olan Zehra (Budunç) Hanım'dı (Yüceer, 2005: 11-12). İstiklâl Madalyası sahibi olan Zehra Hanım, 1931 y1lı itibariyle Himaye-i Etfal Cemiyeti'nin kreşlerinden birinde müdirelik görevini sürdürüyordu. Millî Mücadele döneminde vatana yaptığı hizmetler sebebiyle Yunanlılar tarafından 18 kişiyle birlikte önce Selânik Hapishanesine, oradan da Milo Adası'na götürülmüş, dokuz ay tutukluluktan sonra Cumhuriyet Hükümeti sayesinde yurda dönebilmişti (R.K., Bursanın gece hayatı da pek caziptir, 1931).

Bir diğer kahraman ise Karakuş Ahmed'ti. Dağdibi köyünden olan Karakuş Ahmed'in hemen herkes tarafından tanındığını belirten muhabir onunla Halk Fırkası'nda karşılaşmış ve sohbet etmiştir. Yunan 
işgali sırasında Bursa'daki teşkilat ile Kuvayi Milliye arasında posta taşımış olan bu kahraman artık beyaz sakalının çevrelediği yüzünde geçmişin bin bir destanı okunan bir hâldeydi. İstiklal madalyasına sahipti. Ancak muhtaç hâle gelmiş olduğundan, kendisine "Hıdematı Vataniye" tertibinden maaş bağlanmasını talep ediyordu. Ragıp Kemal Bey bu konuda şu yorumu yapmıştır:

"Bu kahraman köylünün menakıbi vatanperveranesini anlattıkları zaman maziyi şöylece bir gözümün önünden geçirdim ve dedim ki Bursanın karagünlerinde kendini tehlikeye atan bu şerefli insan şimdi dilenecek bir hâle getirilmemeli idi!! Vatana hizmet edenlerin mes'ut bir hayata nailiyetleri nesli ati için bir nümunei teşvik olurdu!" (R.K., Bursanın gece hayatı da pek caziptir, 1931).

Muhabirin görüşemediği hâlde adını zikrettiği ve hâlini merak ettiği bir başka Millî Mücadele kahramanı ise Muhallebici Mustafa Dayı idi. Verdiği bilgiye göre Bursa'nın Maksem Mahallesi'nde hâlâ muhallebicilikle geçimini sağlamakta olan bu kişi, işgal döneminde Bursa'dan Kuvayi Milliye tarafına pek çok kişiyi kaçırmıştı (R.K., Bursanın gece hayatı da pek caziptir, 1931).

\section{Sonuç}

1930'lu yılların ilk yarısında Anadolu ve Trakya'yı dolaşarak gezi yazıları kaleme alan Emekli Kurmay Albay Ragıp Kemal Cantürk 1931-34 yıllarında Bursa vilâyetini altı kez ziyaret etmiştir. Bu ziyaretlerdeki izlenimlerini anlattı̆̆ gezi yazılarından on sekizinin içeriği Bursa kenti ile ilgilidir.

Cantürk, Bursa gezilerini anlattığı tüm yazılarında kentin doğal güzelliklerinden, tarımsal zenginliğinden, ürünlerinin bolluğundan ve ucuzluğundan övgüyle söz etmiştir. Ayrıca ürün ve hizmet fiyatları hakkında bilgi vermiş, ucuzluğu ve pahalılığı konusunda yorumlar yapmıştır.

Uludağ Üniversitesi Fen-Edebiyat Fakültesi Sosyal Bilimler Dergisi Uludağ University Faculty of Arts and Sciences Journal of Social Sciences Cilt: 22 Sayı: 41/Volume: 22 Issue: 41 
Muhabirin ziyaretleri Dünya Ekonomik Krizi'nin en etkili olduğu yıllarla örtüşmesine rağmen Bursa'daki ekonomik faaliyetlerin hâlâ canlılı̆̆ını koruduğu görülmektedir. İpek tezgâhlarına hammadde yetmediği için başka vilâyetlerden ipek alınmakta, bazı aksaklıklara rağmen merinos koyun yetiştiriciliği sürmekte ve yeni kurulan İpek İş Fabrikası yoğun bir şekilde çalışmaktaydı.

Kamu hizmetleri açısından bakıldığında muhabirin çok büyük problemlerden söz ettiği görülmemektedir. Başta belediye olmak üzere kentin imarı için adımlar atılmaktaydı. Bursa Ovası 1slah ediliyordu. Henüz istendik hedeflere ulaşılamamış olsa da eğitimde yoğun bir faaliyet söz konusuydu. Örnek gösterilebilecek okullar mevcuttu. Asayiş sorunu yoktu. Ancak kent içi su dağıtımı ile hem kent içi hem de vilâyet çapındaki ulaşımda aksaklıklar vardı.

Cantürk'ün üzerinde en çok durduğu konulardan biri de Bursa'nın gelişmekte olan turizmidir. Verdiği bilgilere göre ulaşım kolaylığı, doğal güzellikleri, kaplıcaları ve ucuzluğu kenti çekim merkezi hâline getiriyordu. Ayrıca yeni kurulan Turing Kulübü Bursa Şubesi turizmi geliştirmek için aktif rol oynuyor ve olumlu sonuçların ortaya çıkmasını sağlıyordu. Yeni yapılan otelin yanı sıra Dağ Sporları Kulübü de Uludağ'ın turistik değer kazanmasında etkili oluyordu.

\section{Bilgi Notu}

Makale araştırma ve yayın etiğine uygun olarak hazırlanmıştır. Yapılan bu çalışma etik kurul izni gerektirmemektedir.

\section{Kaynakça}

Aladağ, Ç. (2004). Cumhuriyet döneminde Bursa'da kent kültürünün geliştirilmesine yönelik faaliyetler (1935-1950). (Yayımlanmamış yüksek lisans tezi). Bursa: Uludă̆ Üniversitesi Sosyal Bilimler Enstitüsü. 
Bayrak, M. (1992). Türkiye'yi kimler yönetti (1920-1992). Y1lmaz Yayınları.

Bilgi, S. G. (2006). Erken Cumhuriyet Dönemi'nde Bursa'da günlük yaşam (1923-1950). (Yayımlanmamış yüksek lisans tezi). Bursa: Uludağ Üniversitesi Sosyal Bilimler Enstitüsü.

Bursa yolunda bir şekâvet. (1933, Haziran 3). Cumhuriyet, s. 2.

Cantürk, R. K. (1938). Akll hocası. Bürhaneddin Matbaası.

Cantürk, R. K. (1939). Akıl hocası (II. Kısım). Halk Basımevi.

Genelkurmay Başkanlığı (2010). Türk İstiklal Harbi'ne katılan alay ve tugay komutanlarının biyografileri. C. II, Genelkurmay Askeri Tarih ve Stratejik Etüt Başkanlığı.

Kaprol, T. (2002). Cumhuriyet sonrası 1930-1950 y1lları arasında Bursa'da mimari gelişim. Uludă̆ Üniversitesi Mühendislik-Mimarlık Fakültesi Dergisi, 7(1), 171-184.

Kaya, M. (1999). 1918-1950 yılları arasında Bursa Kazasinın sosyal ve ekonomik durumu. (Yayımlanmamış doktora tezi tezi). İzmir: Ege Üniversitesi Sosyal Bilimler Enstitüsü.

Kemal Ragıp (1933, Eylül 22). Bursada dağ sporları çok rağbet görüyor. Akşam, s. 10.

Musa (1933, Haziran 11). Bursa yolundaki soygun. Cumhuriyet, s. 3.

Öztürk, Y. (2014). Kuruluşundan 1950'ye kadar Bursa Belediyesi ve hizmetleri. (Yayımlanmamış doktora tezi tezi). Erzurum: Atatürk Üniversitesi Sosyal Bilimler Enstitüsü.

R.K. (1931, Mart 29). Bursa, bir fabrikalar şehri halini ald1. Milliyet, s. 6.

R.K. (1931, Nisan 4). Bursa, maarifi çok mütekâsif bir şehirdir. Milliyet, s. 2. 
R.K. (1931, Teşrinievvel 19). Bursalıların dertleri. Milliyet, s. 6.

R.K. (1931, Nisan 28). Bursanın gece hayatı da pek caziptir. Milliyet, s. 7.

Ragıp Kemal (1931, Eylül 6). Bursada yapılan yeni binalar. Milliyet, s. 6.

Ragıp Kemal (1931, Eylül 25). Bursaya rağbet. Milliyet, s. 6.

Ragıp Kemal (1932, Kânunusani 1). Bafra sıtmadan bunalmış vaziyettedir. Milliyet, s. 7.

Ragıp Kemal (1932, Şubat 5). Bursadaki merinoslar nasıl ıslah ediliyor? Milliyet, s. 6.

Ragıp Kemal (1932, Eylül 17). Kaplıca şehrinde göze çarpan şeyler. Milliyet, s. 7.

Ragıp Kemal (1933, Eylül 6). Bursa bir sene içinde çok değişti. Akşam, s. 7.

Ragıp Kemal (1933, Eylül 13). Bursa bu sene çok kalabalık ve eğlenceli. Akşam, s. 7.

Ragıp Kemal (1933, Eylül 23). Bursa ve Mudanyada yılan avcıları. Akşam, s. 7.

Ragıp Kemal (1933, Eylül 17). Bursa vilâyetinde hayvan hastalıklarile mücadele. Akşam, s. 10.

Ragıp Kemal (1933, Eylül 19). Bursanın kıymetli bir irfan müessesesi. Akşam, s. 10.

Ragıp Kemal (1933, Eylül 14). Yol parasını yol inşaatına hasretmek lâzım. Akşam, s. 7.

Ragıp Kemal (1934, Eylül 30). Bursa ovasındaki sulama ve kurutma ameliyat1. Akşam, s. 8.

Uludağ Üniversitesi Fen-Edebiyat Fakültesi Sosyal Bilimler Dergisi Uludağ University Faculty of Arts and Sciences Journal of Social Sciences Cilt: 22 Sayl: 41 / Volume: 22 Issue: 41 
Ragıp Kemal (1934, Eylül 29). Bursada hararetli bir belediye faaliyeti var. Akşam, s. 8.

Ragıp Kemal (1934, Teşrinievvel 16). Bursada İpekliler. Vakit, s. 8.

Samsunda tutulan Bursa soyguncuları dün sabah İstanbula getirildiler. (1933, Temmuz 25). Cumhuriyet, s. 1, 3.

Sedad (1934), Bursa 1934 yıllı̆̆g. Bursa Vilayet Matbaası.

T.C. Devlet Yılllğg 1929-1930 (1930). Matbuat Umum Müdürlüğü.

Türkiye Işs Bankasının On Yılı 1924-1934 (1934). Devlet Matbaası.

Yüceer, S. (2005). Tanıkların anlatılarılla Bursa tarihi. Uludağ Üniversitesi Kent Tarihi ve Araştırmaları Merkezi. 


\section{EXTENDED ABSTRACT}

Retired Staff Colonel Ragip Kemal Cantürk worked as a reporter in newspapers named Milliyet, Akşam, and Vakit (Kurun), which were among the most important media organs in Turkey, between the years 1930-36. He traveled Anatolia and Thrace on behalf of these newspapers and wrote his impressions in the form of letters.

Cantürk focused primarily on public services such as education, health, transportation, and municipal work in the places he traveled. Economic activities, local history and culture, and the heroes of the national independence war were also among his main topics of interest. His letters included both an attempt to praise the recently formed republican regime's effective services and a critical point of view to correct deficiencies and failures.

Ragıp Kemal Cantürk visited the provinces around the Sea of Marmara more frequently since they were both easily accessible and on the passage route. One of these provinces was Bursa. Visiting the city of Bursa and its districts six times between the years 1931-1934, Cantürk wrote a lot of travel writings. Eighteen of them mentioning the city center of Bursa are the subject of this study.

According to the information given by Ragip Kemal, Bursa, which was an important city with its natural, historical, and economic richness, maintained its importance and continued its development in the first half of the 1930s. In particular, considerable steps were taken in the field of tourism. A tourist hotel was built and a $c l u b$ was opened for mountain and winter sports in Uludag. The Bursa Branch of the Touring and Automobile Club of Turkey was opened under the chairmanship of Mayor Mr. Muhidin and this club was trying to develop tourism in the city through various activities. On the other hand, thermal tourism continued to attract visitors to the city as it was before. In addition, existing thermal facilities were being developed and new facilities were being built and opened to service.

Visiting the nursery schools opened by the Himaye-i Etfal Cemiyeti (Child Protection Agency) as well as the Necati Bey Institute for Girls and military high school in the city, Ragip Kemal Cantürk especially liked the nursery schools and wanted these institutions to become widespread throughout Turkey.

Although it was the years when the Global Economic Crisis prevailed, Bursa was not quite affected by this crisis according to the information given by the reporter. There were 473 active looms in the city and 360 tons of silk were woven per year. Vegetable and fruit prices were quite affordable. The newly established silk factory was 
operating intensively. However, there were some problems regarding merino sheep breeding, which was tried to be improved in the region.

A well-coordinated government office had not yet been put into service in Bursa. However, in the same years, significant changes were taking place in the urban fabric. The municipality was building new roads, improving existing roads, establishing new facilities, and putting them into service. In addition, various organizations had built new buildings. Some old buildings were being demolished. Social life was also very lively in the city. Movie theaters, parks, coffee houses, tea gardens, and thermal springs were all parts of daily life. On weekends, Mudanya and Uludag were preferred.

The most significant problems pointed out by Ragip Kemal Cantürk, who mostly spoke of Bursa in glowing terms, were the inconveniences in the construction of the roads throughout the province and the water problem inside the city. According to the information given by him, there were serious problems especially in the distribution and purification of the water. In addition, the municipality could not put the bakers into order regarding the bread. There were also some problems in the tourism sector. Despite the abundance and affordable prices in the city, most of the restaurants were servicing expensive and poor-quality food to their customers. Hotelkeepers and thermal managers, on the other hand, were experiencing difficulties in terms of both income and expenditure. 